\title{
The influence of the Great Falls Tectonic Zone on the thrust sheet geometry of the southern Sawtooth Range, Montana, USA
}

\author{
C. M. BURBERRY* \& J. M. PALU \\ Department of Earth and Atmospheric Sciences, University of Nebraska-Lincoln, \\ 214 Bessey Hall, Lincoln, Nebraska 68558-0340, USA
}

(Received 3 November 2015; accepted 1 May 2016; first published online 3 June 2016)

\begin{abstract}
The reactivation potential of pre-existing deep-seated structures influences deformation structures produced in subsequent compression. This contribution investigates thrust geometries produced in surface thrust sheets of the Sawtooth Range, Montana, USA, deforming over a previously faulted sedimentary section. Surface thrust fault patterns were picked using existing maps and remote sensing. Thrust location and regional transport direction was also verified in the field. These observations were used to design a series of analogue models, involving deformation of a brittle cover sequence over a lower section with varying numbers of vertical faults. A final model tested the effect of decoupling the upper cover and lower section with a ductile detachment, in a scenario closer to that of the Sawtooth Range. Results demonstrate that complexity in surface thrust sheets can be related to heterogeneity within the lower sedimentary section, even when there is a detachment between this section and the rest of the cover. This complexity is best observed in the map view, as the models do not show the deep-seated faults propagating into the cover. These results were then used to predict specific locations of discrete basement fault strands in the study area, associated with what is generally mapped as the Scapegoat-Bannatyne Trend. The deep-seated faults are more likely to be reactivated as strike-slip features in nature, given the small obliquity between the ENE-directed compression direction and the NE-oriented basement faults. More generally, these results can be used to govern evaluation of thrust belts deforming over faulted basement, and to predict the locations of specific fault strands in a region where this information is unknown.
\end{abstract}

Keywords: analogue models, remote sensing, Sawtooth Range, fault reactivation, pre-existing faults, Scapegoat-Bannatyne Trend.

\section{Introduction}

Along-strike variation deformation style within present-day crustal deformation belts is best understood in the context of underlying pre-existing or inherited structures in the region (Holdsworth, Butler \& Roberts, 1996; Audet \& Burgmann, 2011; Huerta \& Harry, 2012). On a large scale, pre-existing deep-seated faults typically partition the overlying deformation belt into zones of distinct deformational style. Major faults may show complex, partial reactivation structures such as compartmentalizing the belt structures, nucleating folds and controlling the basement contractions (Butler, Tavarnelli \& Grasso, 2006). A clear example of this is the longitudinal variation in the geometry of the Zagros Simply Folded Belt, where N-S-oriented faults such as the Kazerun Fault separate the Fars and Lurestan salients from the Dezful embayment (Hessami, Koyi \& Talbot, 2001; Bahroudi \& Koyi, 2003; Sepehr \& Cosgrove, 2005). Present literature typically considers the relationship of reactivated fault zones to regions of economic importance (e.g. McMechan, 2012; Burberry, 2015b). Studies of specific structures (e.g. Molliex et al. 2010; Said et al. 2011; Huerta \& Harry, 2012) indicate that both subsequent structure

*Author for correspondence: cburberry2@unl.edu and facies changes are affected by the motion of reactivated, deep-seated faults. Many economically viable deposits in Canada are associated with reactivated, deep-seated fault zones, expected to be related to fluid flow patterns (McMechan, 2012). An alternative view of longitudinal variation in structural style can be ascribed to variations in sediment thickness and therefore wedge width (Boyer, 1995). In this model, the deformation of thicker sediments gives rise to a wider thrust belt than does the deformation of thinner sedimentary packages (Boyer, 1995). Sedimentary prism thickness variations along strike may be constrained by the geometry of the basement; thus this model is not independent of the contribution of basement features. Similarly, along-strike changes in stratigraphy contribute to along-strike changes in structural style in the Zagros Simply Folded Belt. The Hormuz Salt is present in the Fars and Lurestan salient, and not in the Dezful embayment (Bahroudi \& Koyi, 2003). Again, however, the distribution of the Hormuz Salt is constrained by the locations of the basement faults (Burberry, 2015a).

The nature of the displacement on a pre-existing fault, affected by a subsequent stress, is a function primarily of the obliquity of the fault to the imposed stress (Letouzey, 1990). Former reverse faults may be reactivated as strike-slip or transpressive systems, particularly at low convergence angles, which explains the 
geometry of the Giudicarie fault system in the Eastern Italian Alps (Viola, Odonne \& Mancktelow, 2004). Compression across a previously deformed basement shear zone is thought to be responsible for the pattern of transpressional cover faulting and folding in the Itacaiunas belt, Brazil (Pinheiro \& Holdsworth, 1997). Compressional deformation across an existing deformed basement in the Junggar Basin, NW China, is accommodated by partitioning between pure strike-slip faults on the basin margins and transpressional thrusting within the basin itself (Allen \& Vincent, 1997). Natural systems therefore display a range of behaviours above a pre-existing fault depending on the obliquity of the imposed stress to the pre-existing structure.

Analogue models have been used to demonstrate the effect of inherited structures on large-scale thrust-belt geometry (Marshak, Wilkerson \& Hsui, 1992; Macedo \& Marshak, 1999; Lickorish et al. 2002; Bahroudi \& Talbot 2003; Lacombe et al. 2003; Weil \& Sussman, 2004; Gutowski \& Koyi, 2007). For example, Macedo and Marshak (1999) demonstrated the strong effect that basement geometry may have on the development of an orogenic arc, as has been postulated for the Appalachian chain (e.g. Thomas, 1977, 2004). On a smaller scale, Viola, Odonne \& Mancktelow (2004) used analogue models to demonstrate the reactivation of a thrust fault under a transpressive regime, explaining the geometry of the Guidicarie fault system in the Italian Eastern Alps. Large-scale finite-element modelling demonstrates that a pre-existing structural system can exert significant control on subsequent deformation styles (Huerta \& Harry, 2012). Nilfouroushan et al. (2013) used numerical models to demonstrate that basement rheology and depth of the brittle-ductile transition zone affect the ways in which basement faults can be reactivated. Basement-involved thrusts in the hinterland of a fold-thrust belt are most likely where the brittleductile transition is deep, whereas more distributed deformation and a lack of major hinterland basementinvolved thrusts are modelled where the brittle-ductile transition is relatively shallow.

Analogue modelling has also been used to demonstrate the deformation patterns expected above a pre-existing fault reactivated as a strike-slip system (Richard, Mocquet \& Cobbold, 1991). These models demonstrate the en échelon pattern of folding and thrusting expected in a pure strike-slip system. As the obliquity of the imposed stress to the existing fault increases, the faulting patterns in the overlying cover become more complex (Richard, Naylor \& Koopman, 2008). Some deformation, particularly in brittle systems, only occurs at depth and is not visible at the surface (Richard \& Krantz, 1991). Oblique slip on a reactivated basement fault produces localized deformation in the cover sequence above the reactivated fault in a brittle system, and a wider zone of deformation in a system where the basement and cover are decoupled by a thick ductile layer (Richard, 1991). Thus, it is apparent that natural deformation patterns can be reproduced by carefully scaled analogue models, and the controlling factor is again the obliquity between the imposed stress and the existing fault.

The aim of the present contribution is to investigate the deformation patterns produced in surface thrust sheets of the Sawtooth Range (hereinafter STR) deforming over a previously faulted lower-cover section (the Cambrian section developed above the Great Falls Tectonic Zone, GFTZ). The study area is shown in Figure 1. We begin with the hypothesis that the preexisting faults of the GFTZ, such as the ScapegoatBannatyne Trend, are the main influencing factor on the pattern of branch lines within the thrust sheets of the Sawtooth Range. We test several configurations of lower-cover faults overlain by an entirely brittle system, in order to suggest a probable configuration for the faults making up the Scapegoat-Bannatyne Trend. Lastly, we add a detachment layer between the lower and upper cover, to demonstrate that, even when the faulted section and upper cover are separated by a detachment, the surface deformation is still affected by the fault geometry. All model scenarios are simplified relative to the natural system. The pre-existing faults are thought to be only slightly oblique to the imposed compression in the study area, and this situation is replicated in our models.

The study area has been chosen because of the apparent large-scale effect of the edges of the GFTZ on the overall architecture of the STR. To the north, there is a significant lateral ramp in the overlying Precambrian thrust sheets (grey shaded in Fig. 1) and the STR plunges underneath this lateral ramp. To the south, a pronounced oroclinal bend in the Precambrian thrust sheets, in the vicinity of Augusta, marks the region where the fold-thrust belt overlies a named trend in the GFTZ, the Scapegoat-Bannatyne Trend (Fig. 1; Reinecke, 1989; Gardner \& Achuff, 1989). This trend also appears to affect fault geometries at the top of the Madison Group within the STR, and may influence the folding geometries noted in the area (Gardner \& Achuff, 1989). In addition, fault reactivation within the GFTZ has also created the Marias Saddle within the Sweetgrass Arch - Kevin-Sunburst Dome structure (Lorenz, 1982). Thus, it is plausible that individual trends within the GFTZ have affected the geometry of the overlying thrust sheets.

\section{Geologic setting}

The Sawtooth Range forms the frontal region of the Northern Disturbed Belt (Sevier Orogen) in the Northern Rocky Mountains, North America. The Northern Disturbed Belt of Montana can be divided into four sub-belts (Mudge, 1982b) of which the Sawtooth Range makes up sub-belts 2 and 3 (labelled Sawtooth Range in Fig. 1a), and the Lewis-Eldorado-Hoadley thrust slab makes up sub-belt 4 (grey shaded area in Fig. 1a). The Lewis-Eldorado-Hoadley thrust slab may be the youngest fault system in the area, forming concurrently with the Continental Divide Syncline in the same stress field (Mudge \& Earhart, 1980). Beneath this slab, the 



Figure 1. Regional geology of the Sawtooth Range, Montana, with an inset map showing the regional context. The inset base map is from Geomapapp, and GFTZ marks the extent of the Great Falls Tectonic Zone. The main map (a) is compiled from references within the text. Key basement features mentioned in the text are marked. The black box shows the location of the study area in Figures 3,5 and 18. (b) A cross-section modified from Fuentes, DeCelles \& Constenius (2012).

Sawtooth Range is a thin-skinned foreland fold-thrust belt, and consists of a narrow band of regional-scale thin-skinned thrust faults and related folds (Mudge, 1982a; DeCelles, 2004; Fig. 1b). On closer inspection, the Sawtooth Range consists of abundant imbricate thrusts with small offsets and tight asymmetric folds. Seismic and well data indicate that potential detachment surfaces occur in the upper Cambrian, top Devonian and intra-Mississippian units in the hinterland, and within the Cretaceous section in the foreland (Singdahlsen, 1984; Holl \& Anastasio, 1992). Crustalscale seismic lines (e.g. Consortium for Continental Reflection Profiling, COCORP) suggest that the crystalline basement underlying the Sawtooth Range is not always included in the thrust sheets, despite basement involvement in the hinterland and that the belt can be considered dominantly thin-skinned (Yoos et al. 1991; Boyer, 1992, Holl \& Anastasio, 1992).

The Sawtooth Range is underlain by the NE-trending Great Falls Tectonic Zone (GFTZ), a $250 \mathrm{~km}$ wide zone of intense basement deformation that stretches from the Idaho batholith into Saskatchewan (Mudge \& Earhart, 1977; Boerner et al. 1998; Sims et al. 2004). The GFTZ is defined by a variety of NE-trending features (Finn \& Sims, 2005), including a series of high-angle faults and shear zones, dyke swarms and gravity and magnetic anomalies, forming a broad zone of collinear NE-trending structures across the western Montana thrust belt (O’Neill \& Lopez, 1985). Landsat imagery also reveals a marked lineament with surface 
structures aligned over the Scapegoat-Bannatyne Trend (Mudge \& Earhart, 1979). In later work, the ScapegoatBannatyne Trend and the similarly oriented Pendroy Fault were considered fracture systems in the subsurface (Mudge, 1982b). Within the Sawtooth Range and associated foreland basin, there are a number of small hydrocarbon pools, such as the Teton Knowlton Field (Napier, 1982), that appear to be associated with these lineaments. The GFTZ is considered to have been episodically active from the late Proterozoic to the Holocene (O’Neill \& Lopez, 1985).

The GFTZ was previously considered an Archaean shear zone, periodically reactivated throughout geological history (Boerner et al. 1998); however, recent data imply that the GFTZ is a Palaeoproterozoic suture between the Wyoming and Medicine Hat Archaean basement blocks, related to the subduction of an ocean basin around $1.8 \mathrm{Ga}$ and thus analogous to the Churchill-Superior boundary (O'Neill \& Lopez, 1985; Holm \& Schneider, 2002; Mueller et al. 2002). Glacier National Park, north of the Sawtooth Range, is the continuation of this structural low (Kulik, 1982) which is bounded to the south by a transverse basement structure associated with a ramp in the Lewis Thrust. In addition, some authors locate the Sawtooth Range (and other parts of the Rocky Mountain chain) above the rifted margin of the supercontinent Columbia (Sears $\&$ Price, 2002; Dickinson, 2004). This, therefore, creates a highly heterogeneous basement, indicating that basement geometry must have some influence on the development of the overlying fold-thrust belt, despite the mostly thin-skinned nature of the fold-thrust belt (Hardebol et al. 2007).

Broadly, the sedimentary structure is that of a composite prism, with the older wedge composed of continental margin shelf deposits and the younger wedge composed of marine and non-marine clastics shed from uplifts in the west (Fig. 2). The oldest sediment in the region is the Precambrian Belt Supergroup, a sequence of homogeneous fine-grained clastic sediments deposited in a shallow salt-water basin that covered a wide area (Childers, 1963; Windley, 1986). This unit crops out in the Lewis-Eldorado-Hoadley thrust system. Rifting of the basement to form the Columbia Rift Margin and deposition of the overlying clastic slope deposits, followed by uplift and erosion, occurred at the end of the Precambrian. The Cambrian-Cretaceous sequence can be summarized as Cambrian-Devonian shale-rich passive margin units overlain by the Misissippian Madison Group and overlying Jurassic - lower Cretaceous clastic formations. This sequence is overlain by the Colorado Group Shales from the upper Cretaceous, followed by clastic Cretaceous units related to the transgressions and regressions of the Cretaceous Interior Seaway.

The Cambrian succession of shales and limestones was deposited on the Alberta Shelf, of which the Sawtooth Range is the southern portion. The upper five Cambrian units are exposed within the central Sawtooth Range (Deiss, 1943; Mudge, 1982b) although

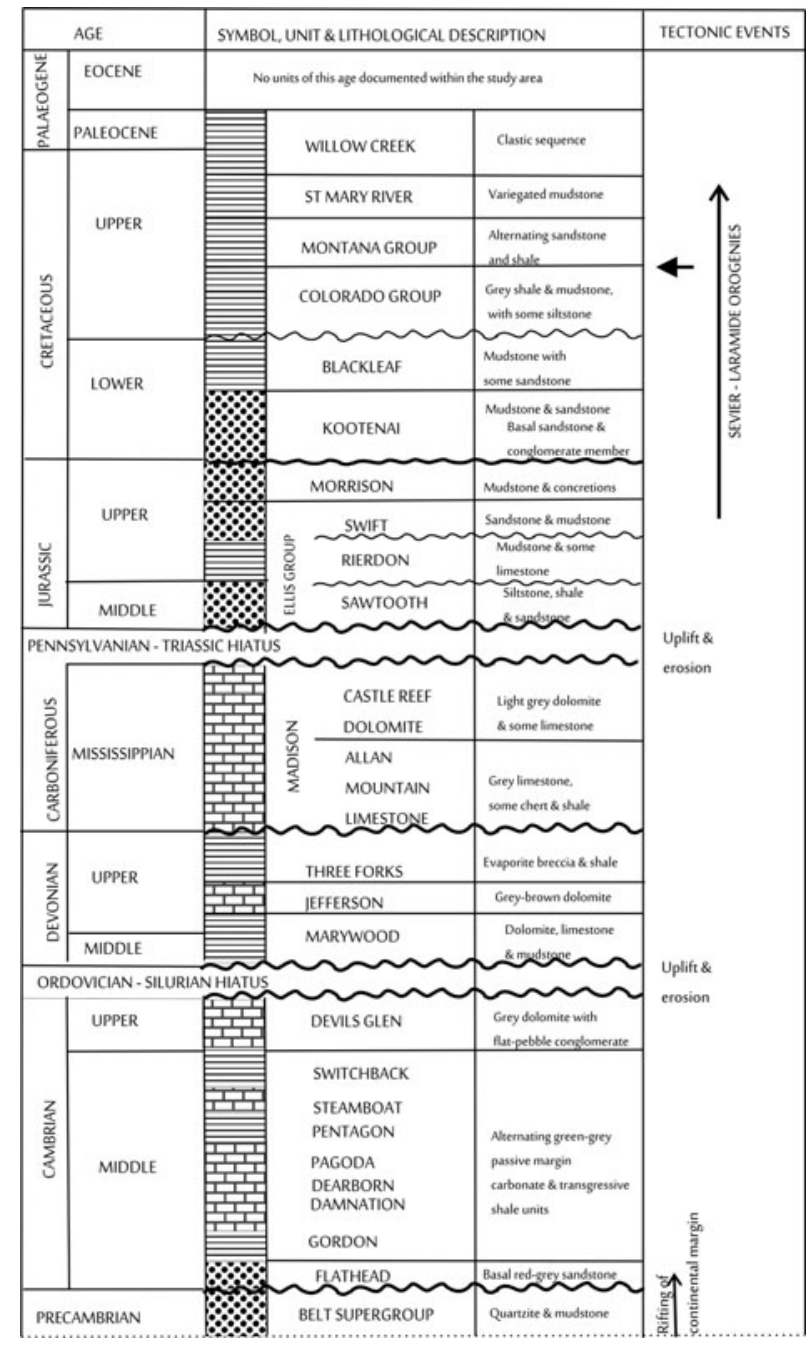

Figure 2. Tectonostratigraphic column for the study area, compiled from references within the text.

only the upper Cambrian unit is exposed within the study area. The total thickness of the Cambrian units in the study area is c. $385 \mathrm{~m}$ (Gardner \& Achuff, 1989), but isopach maps show that the Cambrian units vary in thickness around the GFTZ (O'Neill \& Lopez, 1985), suggesting that active faulting influenced the deposition of this unit. The Ordovician-Silurian hiatus is overlain by Devonian units averaging $300 \mathrm{~m}$ thick (Deiss, 1943; Gardner \& Achuff, 1989). The Devonian units consist of interlayered shale and dolomite units, and frequently behave as a detachment unit within the Sawtooth Range (e.g. Holl \& Anastasio, 1992). The Mississippian Madison Group, averaging $440 \mathrm{~m}$ in thickness (Deiss, 1943; Gardner \& Achuff, 1989), unconformably overlies the Devonian Three Forks Formation. The Madison Group consists of the lower Allan Mountain Limestone, and the upper Castle Reef Dolomite members (Nichols, 1983).

The boundary between the Madison and the Ellis group is an unconformity which spans at least $140 \mathrm{Ma}$ (Paull \& Paull, 1991; Dickinson \& Gehrels, 2003). The early Jurassic Ellis is unconformably overlain by the Morrison formation, which is considered to be the 
backbulge sediments of a classic foreland basin system, as thrusting began to the west (DeCelles, 2004). The Jurassic series is $c$. $100 \mathrm{~m}$ thick (Deiss, 1943; Gardner \& Achuff, 1989; Fuentes et al. 2011). The basal Cretaceous unconformity represents the passage of the forebulge towards the east, modified by dynamic subsidence of the lithosphere, and the non-marine Mount Pablo and Kootenai formations are deposited in the foredeep. The Kootenai and Blackleaf Formations together average $400 \mathrm{~m}$ in thickness (Deiss, 1943; Gardner \& Achuff, 1989). In the Aptian, marine inundation begins as the Cretaceous Interior Seaway engulfs the foreland basin system. This is seen in the deposition of the Colorado Group Shales, which average $500 \mathrm{~m}$ in thickness. Various authors (Boyer, 1992; Holl \& Anastasio, 1992; Fuentes et al. 2011; Fuentes, DeCelles \& Constenius, 2012) place the majority of STR deformation as occurring in the Late Cretaceous, after the deposition of the Colorado Group, and synchronous with the deposition of the overlying Montana Group. The Montana Group, and overlying units up to Paleocene in age, are dominantly terrestrial units, representing deposition as the Interior Seaway receded (Fuentes, DeCelles \& Constenius 2012). Thus, the composite prism can reasonably be modelled as a brittle system of interlayered sandstone and carbonates, modified in the last model by the inclusion of the Devonian detachment surface.

\section{Methods}

We used existing maps (e.g. Fuentes, DeCelles \& Constenius 2012), United States Geological Survey (USGS) data and aerial photographs and satellite images to create a map of the thrust geometry in the study area. During this process, particular attention was paid to the location of branch lines within the thrust patterns. We then examined a series of key transects in the field (Fig. 3), in order to search for evidence of transport direction and small-scale deformation in individual thrust sheets. Field measurements included attitude of bedding in the thrust sheets, lithology, location and orientation of small-scale structures and orientation of any mineral lineations or fractures indicating transport direction in the thrust sheets. We then compared the field observations with the thrust map in order to predict some potential orientations of lower-cover faults for testing in the modelling phase of this study. Results from field investigations will be discussed in Section 4.a.

The experimental set-up consists of a box with one moving wall driven by a stepper motor, and two cameras set up and levelled to photograph the top surface of the model and the side view (Burberry, 2015b). The modelling apparatus is $48 \mathrm{~cm}$ wide and each experiment had a starting length of $c .63 \mathrm{~cm}$, but only $30 \mathrm{~cm}$ of the model were used in the final analysis. The base, moving wall and fixed wall are made of waterproofed plywood, and the side walls are made of glass, resulting in a model with a relatively high basal friction. Side

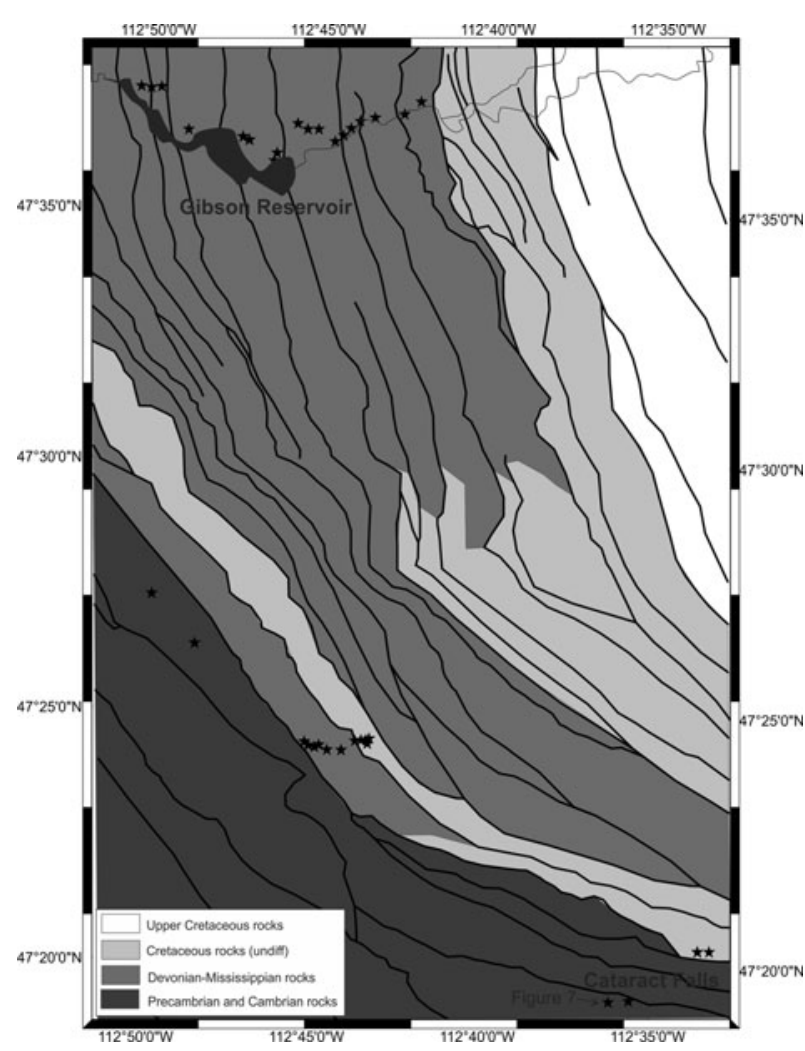

Figure 3. Simplified geologic map of the study area, modified after Fuentes, DeCelles \& Constenius (2012). Solid black lines mark thrust faults. Key areas and the location of Figure 7 are marked. Field sites are marked as black stars.

walls are not lubricated during experimental runs, as the model apparatus is sufficiently wide to obtain results in the centre of the apparatus which are free from edge effects. An empirical rule for avoiding the section of the model affected by edge effects is to avoid a margin equal to or greater than the height of the sedimentary wedge. Typically, representative sections are sliced between 8 and $40 \mathrm{~cm}$ from one side wall, thus leaving a margin of $8 \mathrm{~cm}$ that contains areas of the model affected by edge effects, and $32 \mathrm{~cm}$ that can reasonably be used for analysis. The apparatus is allowed to dry out between experiments and thoroughly cleaned.

Models 1-5 in this study consisted of a lower-section layer of coarser sand (1 cm thick), overlain by four $5 \mathrm{~mm}$ thick layers of finer sand. Sand is poured into the deformation apparatus and smoothed using a scraper, but not compacted. The sand is sifted before use, to separate the finer and coarser fractions. A standard test sieve (\#35) is used, so the material used in the 'fine' layers has a grain-size of less than $0.5 \mathrm{~mm}$ and the material used in the 'coarse' layers has a grain-size of $c .0 .5 \mathrm{~mm}$. Marker layers made of dyed fine quartz sand were used to separate the layers and were used as marker units to visualize subsurface deformation. Model 1 was run as the calibration model, with no lower-cover heterogeneity introduced. Models $2-5$ had vertical, linear cuts (equivalent to inactive fault planes and hereafter referred to as faults) introduced into the lower layer with a knife, in configurations shown in Figure 4. These 
Table 1. Scaling parameters

\begin{tabular}{|c|c|c|c|}
\hline Quantity & Nature & Model & Scaling ratio \\
\hline Acceleration due to gravity $\left(\mathrm{m} \mathrm{s}^{-2}\right)$ & 9.81 & 9.81 & $a_{\mathrm{m}} / a_{\mathrm{n}}=1$ \\
\hline Thickness - Devonian-Cretaceous units & $\begin{array}{l}1740 \mathrm{~m} \\
(1440 \mathrm{~m} \text { brittle, } \\
300 \mathrm{~m} \text { ductile in } \mathrm{M} 6)\end{array}$ & $\begin{array}{l}20 \mathrm{~mm} \\
(16 \mathrm{~mm} \text { sand, } 4 \mathrm{~mm} \\
\text { silicon in M6) }\end{array}$ & $L_{\mathrm{m}} / L_{\mathrm{n}}=1.15 \times 10^{-5}$ \\
\hline Thickness - Cambrian & $800 \mathrm{~m}$ & $10 \mathrm{~mm}$ & $L_{\mathrm{m}} / L_{\mathrm{n}}=1.25 \times 10^{-4}$ \\
\hline Density - cover units $\left(\mathrm{kg} \mathrm{m}^{-3}\right)$ & $2440-2580$ & 1740 & $\rho_{\mathrm{m}} / \rho_{\mathrm{n}}=0.67-0.71$ \\
\hline Density - shale $\left(\mathrm{kg} \mathrm{m}^{-3}\right)$ & $2200-2300$ & 1308 & $\rho_{\mathrm{m}} / \rho_{\mathrm{n}}=0.56-0.59$ \\
\hline Density - Cambrian section $\left(\mathrm{kg} \mathrm{m}^{-3}\right)$ & 2610 & 1730 & $\rho_{\mathrm{m}} / \rho_{\mathrm{n}}=0.66$ \\
\hline Friction coefficient (cover units) & $0.53-0.64$ & 0.59 & $\mu_{\mathrm{m}} / \mu_{\mathrm{n}}=0.92-1.11$ \\
\hline Friction coefficient (Cambrian) & 0.53 & 0.73 & $\mu_{\mathrm{m}} / \mu_{\mathrm{n}}=1.37$ \\
\hline Viscosity of ductile layer in M6 (Pa s) & $1.7 \times 10^{18-19}$ & $5 \times 10^{5}$ & $2.9 \times 10^{-14}$ to -13 \\
\hline Cohesion (cover units) & $60 \mathrm{MPa}$ & $185 \mathrm{~Pa}$ & $C_{\mathrm{m}} / C_{\mathrm{n}}=3.08 \times 10^{-5}$ \\
\hline Cohesion (Cambrian) & $90 \mathrm{MPa}$ & $215 \mathrm{~Pa}$ & $C_{\mathrm{m}} / C_{\mathrm{n}}=6.94 \times 10^{-6}$ \\
\hline Dynamic similarity ratio (avg. cover) & $2.39 \times 10^{-2}$ & $1.06 \times 10^{-7}$ & Ratio $\mathrm{m} / \mathrm{n}=4.44 \times 10^{-10}$ \\
\hline Dynamic similarity ratio (Cambrian) & $3.44 \times 10^{-2}$ & $1.24 \times 10^{-7}$ & Ratio $\mathrm{m} / \mathrm{n}=3.60 \times 10^{-10}$ \\
\hline Shortening rate & $0.2 \mathrm{~cm} \mathrm{a}^{-1}$ & $1.75 \times 10^{4} \mathrm{~cm} \mathrm{a}^{-1}$ & $8.75 \times 10^{4}$ \\
\hline
\end{tabular}

Material properties in nature from Daly, Manger \& Clark (1996) and Schellart (2000).


Figure 4. Initial configurations of Models 1-6, showing the locations of lower-cover faults. (a-e) The initial configurations of Models 1-5 respectively. (f) The configuration of Model 6, with the grey box representing the location of the silicon layer. (g) The stratigraphy used in Models 1-5. (h) The stratigraphy used in Model 6.

configurations were chosen based on results from the remote-sensing phase of the study. Faults were introduced vertically, with a knife, creating a zone of dilation and thus a genuine anisotropy in the material layers (Morley, 1999). Model 6 also had faults introduced into the lower layer, but the cover stratigraphy varied from the other models by including a ductile layer, composed of $4 \mathrm{~mm}$ of a silicon polymer between the lower layer and the upper cover. In nature, this ductile unit is the Devonian mudstone, shale and limestone sequence which acts as a detachment in the thrust sheets of the Sun River Canyon (Holl \& Anastasio, 1992). Table 1 
Table 2. Model data

\begin{tabular}{lcccc}
\hline Model & Start length $\mathrm{mm}$ & $\begin{array}{c}\text { Final length } \\
\mathrm{mm}\end{array}$ & $\begin{array}{c}\text { Shortening } \\
\text { amount mm }\end{array}$ & Shortening \% \\
\hline 1 - calibration & 300 & 214 & 86 & 28.6 \\
2 - one perpendicular fault & 300 & 214 & 86 & 28.8 \\
3 - one oblique fault & 300 & 215 & 85 & 28.3 \\
4 - two oblique faults & 300 & 214 & 86 & 28.8 \\
5 - three en échelon oblique faults & 300 & 219 & 81 & 27.0 \\
6 - two oblique faults + ductile & 300 & 214 & 86 & 28.8 \\
\hline
\end{tabular}

shows start lengths, final lengths (as used in analysis) and shortening amounts of the models. Shortening percentages in the cross-sections and maps are calculated based on the first $30 \mathrm{~cm}$ of the model only, so the long section of the model that is undeformed is ignored. This makes the shortening percentages more comparable with real-world examples.

Photographs were taken of the model surface during set-up, to record the positions of the faults introduced into the lower-cover unit. During shortening, photographs were taken at every $\sim 8 \mathrm{~mm}$ shortening increment as well as of the initial and final configurations. Top-surface photographs were used to track the appearance of new thrust sheets and the geometries of the developing thrust sheets. During analysis, the appearance of each new thrust was documented and the trace of the new thrust fault was marked on the photograph. Any branch lines were also marked. The traces of previously formed thrusts were also marked on the images. Lastly, the positions of the pre-existing faults were overlain, in order to assess the effect of these faults on the geometry of the developing thrust traces, and the density of branch lines visualized using choropleth maps. Sideview photographs were taken to estimate the geometry of the faults at each shortening increment, and to validate the appearance of new thrusts. These images were generally used to confirm the formation of additional thrust faults, so the effect of rotation in the fault strike due to edge effects does not affect the result.

Once each model had been shortened to the desired amount (Table 2), a sand pack was added to preserve the topography and the model was wetted with a soap solution and sliced into cross-sections. If the soap solution is introduced slowly via syringe and light spray at the edges of the model and the top of the sand pack, the liquid does not affect the configuration of the sand grains as seen in side view. Slices were made using a flat-bladed knife, and, with practice, clean cuts can be made that do not distort the structure of the models. Photographs were taken of every cross-section, and representative cross-sections chosen for comparison between models, to assess whether the lower-cover faults affect the geometry of the thrust faults in crosssection. Line drawings of representative cross-sections were produced, the location of the lower-cover faults calculated and marked, and any deviation of thrust fault geometry from the expected shape was noted.

In order to provide realistic simulations of natural examples, analogue models must be geometrically and dynamically scaled to their prototype. A length ratio of $1.15 \times 10^{-5}$ is used in these models, so $5 \mathrm{~mm}$ in the model represents $435 \mathrm{~m}$ in nature. This ratio has been chosen such that the Devonian - Colorado Group sedimentary sequence in the Sawtooth Range, which averages $1740 \mathrm{~m}$ thick, can be represented by a sand pack $20 \mathrm{~mm}$ thick. The 'lower section' or 'basement' in the models consists of the Cambrian units, here modelled at the maximum thickness of $800 \mathrm{~m}$ (O'Neill \& Lopez, 1985). In Model 6, the $20 \mathrm{~mm}$ sand pack is replaced by a sand pack $16 \mathrm{~mm}$ thick underlain by a ductile layer $4 \mathrm{~mm}$ thick. This represents the $300 \mathrm{~m}$ of Devonian shale-rich units which act as a detachment in the study area and are more representative of the rheology of the study area. Models 1-5 are therefore a simplified system, run to test the influence of lowercover faults where the upper cover is not detached from the lower cover. Model 6 is not intended to directly replicate the deformation in the Sawtooth Range, as the silicon used has a viscosity more comparable to salt than shale. However, the model does demonstrate that even with a ductile detachment, faults in a lower unit can affect the geometries of a thrust belt overlying a detachment.

In order to satisfy the requirement for dynamic similarity, a set of dimensionless ratios which relate the physical properties of the natural and analogue materials, respectively, must be similar. The coefficient of internal friction of the material used must be equal or close to the value of the simulated rocks. The coefficient of internal friction of the cover sequence is taken to be $0.53-0.64$ (Schellart, 2000). In contrast, the coefficient of internal friction of the loose sand used in the models is measured as 0.59 (fine sand) and 0.73 (coarse sand), using shear and normal stress measurements within the laboratory (Koyi and Petersen, 1993; Weijermars, 1993; Maillot \& Koyi, 2006). A ratio that indicates dynamic similarity is the ratio of cohesion to density (Schreurs et al. 2006). In these experiments, for the cover rocks, $C_{\mathrm{n}} / \rho_{\mathrm{n}}=3.37 \times 10^{-2}$ and $C_{\mathrm{m}} / \rho_{\mathrm{m}}$ $=1.06 \times 10^{-7}$ (subscripts $\mathrm{n}$ and $\mathrm{m}$ represent nature and model, respectively). The lower-cover units have ratios in nature and the model of $3.44 \times 10^{-2}$ and 1.24 $\times 10^{-7}$, respectively. Dynamic similarity is maintained when the ratios between values for model and nature, in the upper cover and in the lower cover, are similar. The ratio obtained for the upper cover is $4.44 \times$ $10^{-10}$ and for the lower cover is $3.60 \times 10^{-10}$, indicating that dynamic similarity can be considered to be 


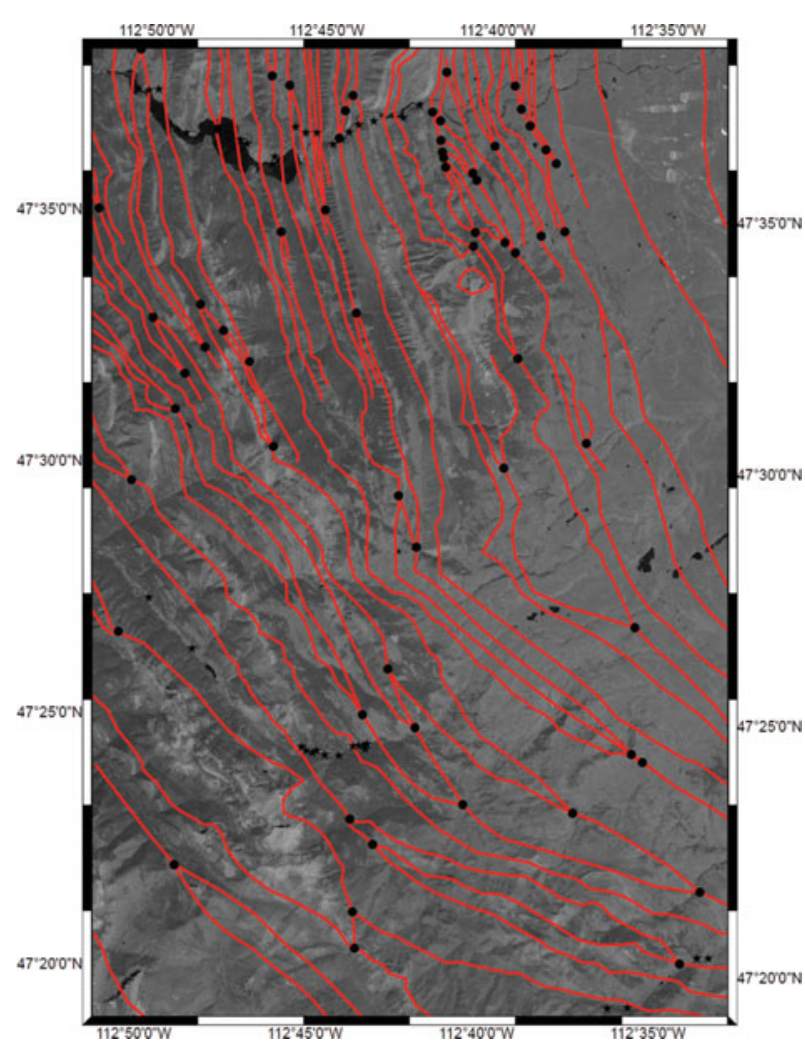

Figure 5. Structural map of the study area overlain on the satellite image from Figure 3. Thrust faults are generated after Fuentes, DeCelles \& Constenius (2012), the USGS map of Montana and remote-sensing observations.

maintained. Finally, the ductile material used in these models, a silicone gum, which is a Newtonian viscous material, approximately simulates the behaviour of less competent shale at shallow crustal levels.



\section{Results}

4.a. Structures within the southern Sawtooth Range

The southern Sawtooth Range is characterized by an oroclinal bend, and by a series of stacked thrust sheets in the Palaeozoic section (Figs 1b, 5). The NE-SWoriented Scapegoat-Bannatyne Trend passes through the region (Fig. 1a). In general, the thrust traces have a low sinuosity, and to the north of the Gibson Reservoir area are oriented N-S. South of the Gibson Reservoir, the thrust traces are oriented NNW-SSE across the rest of the study area. The locations of branch lines between thrust faults are marked in Figure 5 with black dots. There are several clusters of branch lines, such as those to the east of the Gibson Reservoir, those south of the Gibson Reservoir, and those between $4730^{\prime} 00^{\prime \prime} \mathrm{N}$ and $47^{\circ} 35^{\prime} 00^{\prime \prime} \mathrm{N}$. An additional trend of branch lines occurs from the SW corner of the map, to $47^{\circ} 30^{\prime} 00^{\prime \prime} \mathrm{N}$ on the east side. These clusters or trends appear to be discrete and are separated by zones of linear thrust traces. This observation suggests that there may be discrete underlying structures, forming part of the GFTZ, that affect the surface faults in this area.

Fracture data along the Gibson Reservoir transect show four pronounced orientations (Fig. 6a). These directions are $\sim \mathrm{N}-\mathrm{S}, \sim \mathrm{E}-\mathrm{W}, \mathrm{NE}-\mathrm{SW}$ and NW-SE. The most prominent fracture orientation is $\mathrm{N}-\mathrm{S}$, subparallel to the strike of the thrust faults in this area, and interpreted to be formed from outer-arc stretching as the thrust sheet forms a fold over the growing thrust tip. The $\mathrm{E}-\mathrm{W}$-oriented fractures are interpreted to be the downdip direction of the thrust sheets, suggesting an overall shortening direction. The remaining two orientations are thought to be conjugate shear fractures, as at least one of these directions shows sub-horizontal mineral

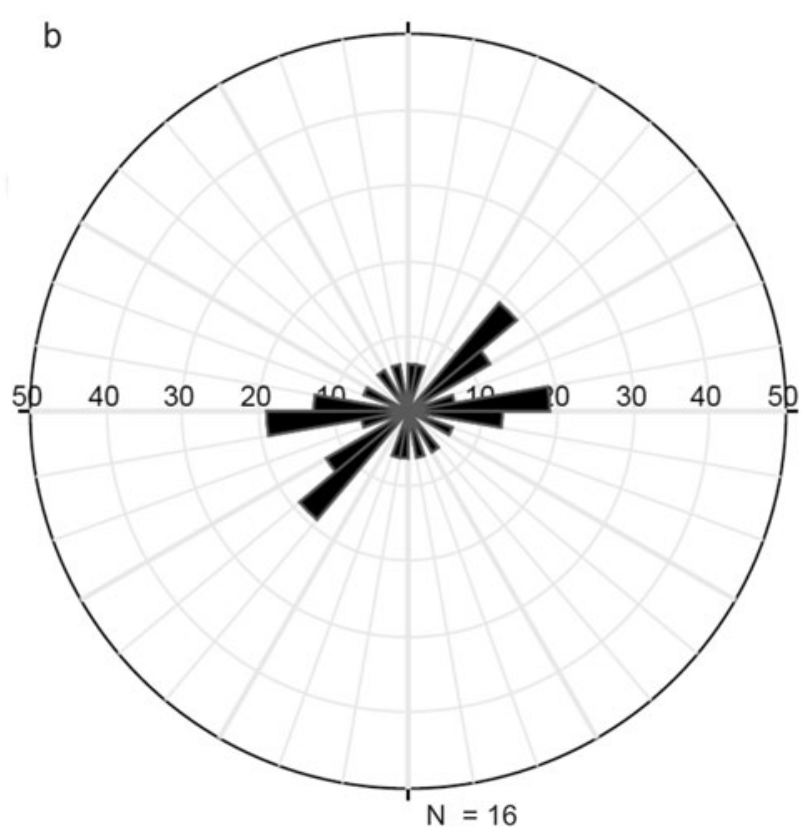

Figure 6. (a) Orientations of macrofractures along the Gibson Dam transect, indicating four key fracture orientations. Two are parallel to the strike and dip of the thrust faults respectively, and a set of conjugate shears can also be seen. (b) Orientations of the fractures containing sub-horizontal mineral lineations. Transport is inferred to be W-E. 

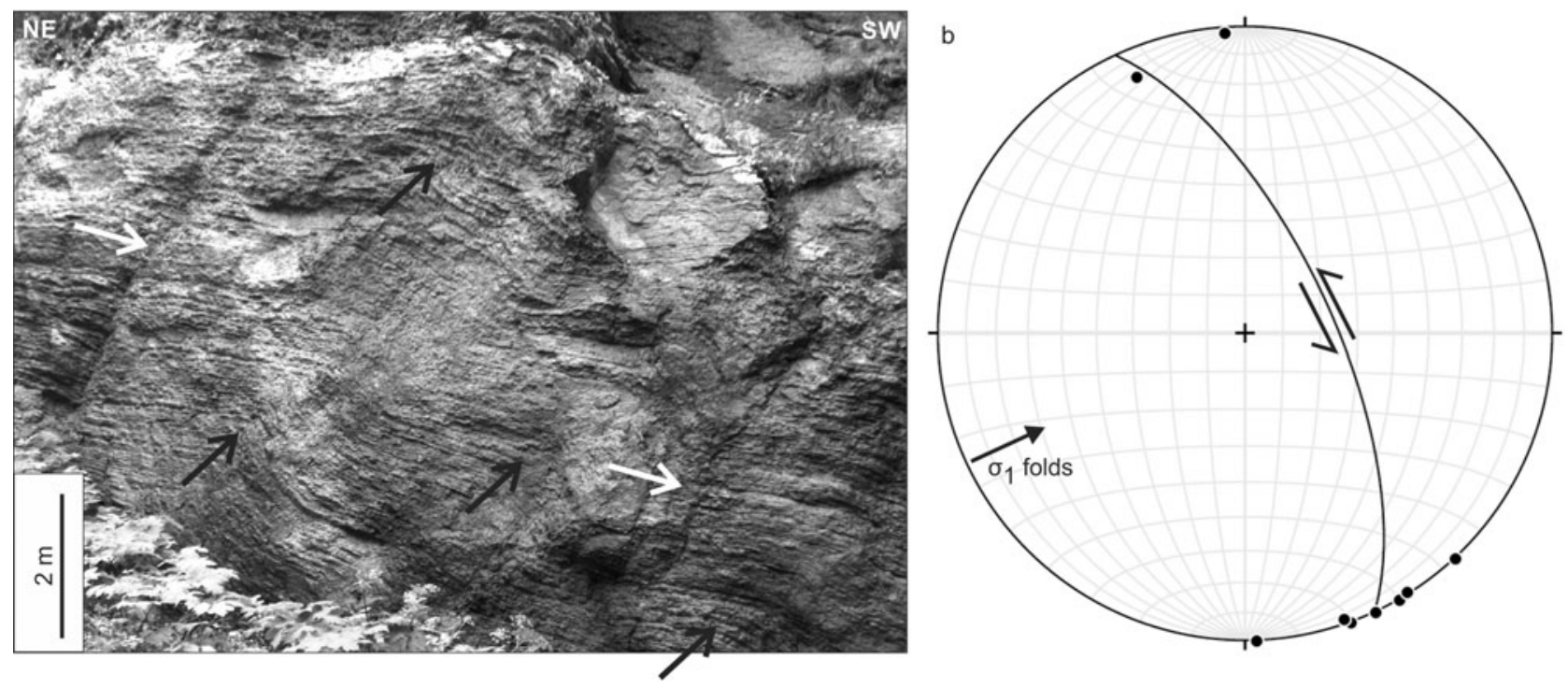

Figure 7. (a) Photograph of folding within the Cambrian units at Cataract Falls. (b) Stereonet showing the orientations of fold hinge lines and a strike-slip fault within the outcrop.
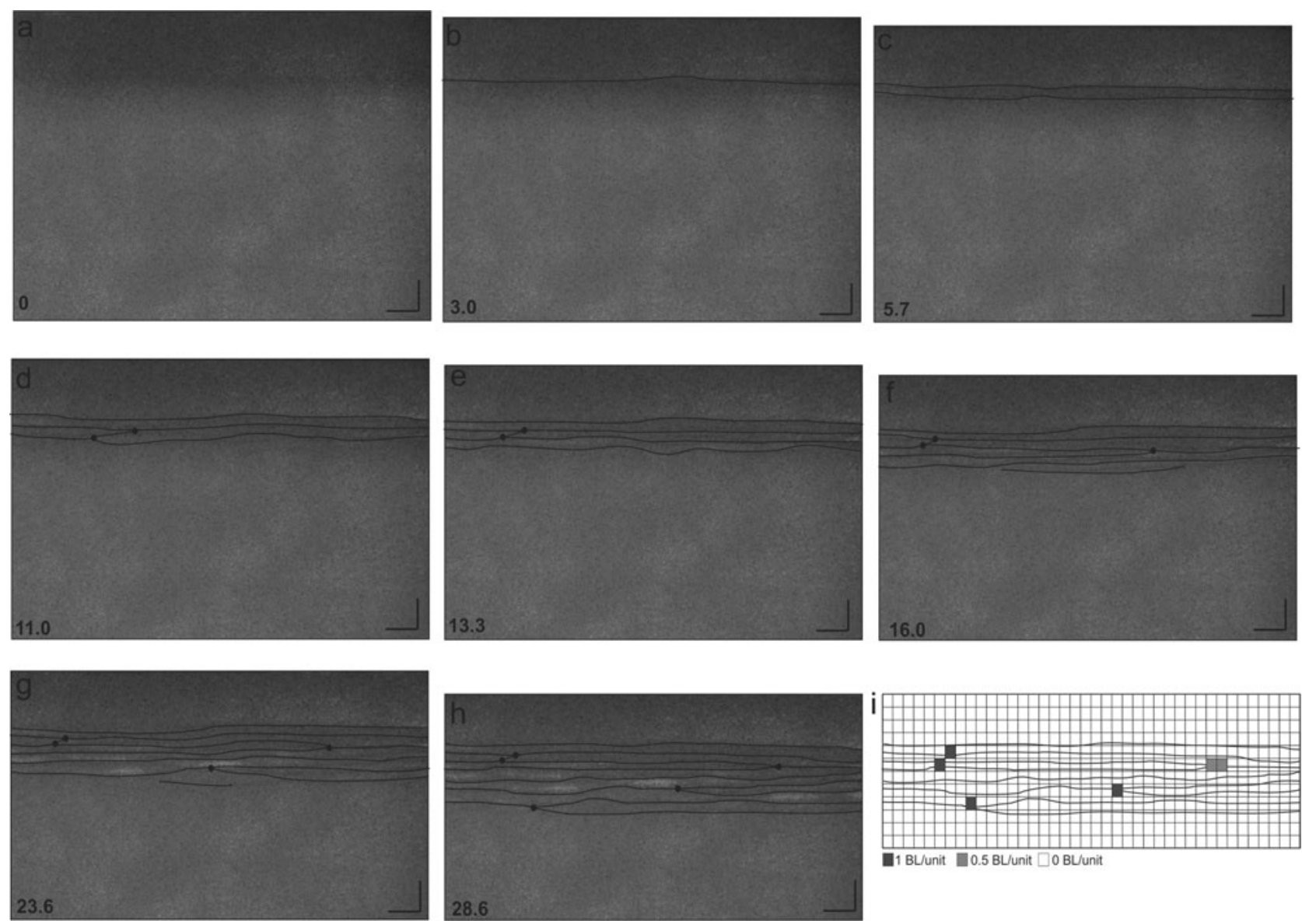

1 BL/unit 0.5 BL/unit $\square 0$ BL/unit

Figure 8. (a-h) Stepwise plan views from Model 1, at successive stages of shortening. The scale bar at the lower right is $3 \mathrm{~cm}$ long. The number at the lower left indicates the percentage shortening at the point the image was taken. Thrust traces are interpreted on each image. Black dots represent branch lines. (i) A choropleth map of branch line density.

lineations (Fig. 6b). Sub-horizontal mineral lineations are also noted on the $\mathrm{E}-\mathrm{W}$-oriented fractures. This distribution of fractures and mineral lineations suggests an overall W-E to WSW-ENE compression direction in this area. However, in the Cataract Falls area, to the south of the study area, a series of minor folds and faults is observed at the base of a large thrust sheet (Fig. 7a; fold hinge lines arrowed black, faults arrowed white). The thrust sheet strikes WNW-SSE (Fig. 5). The fold hinge lines are sub-horizontal and are oriented 



-1 BLunit

Figure 9. Same as Figure 8, but for Model 2. The locations of the pre-existing faults are shown.

NW-SE, indicating a SW-NE regional shortening direction (Fig. 7b). Sub-horizontal mineral lineations on a fault surfaces at this location indicate some NWSE-oriented strike-slip faults within the thrust sheet, indicating a strike-slip component of the deformation. Thus, in this region, the overall deformation style is transpressional, and the regional shortening is likely to be $\mathrm{W}-\mathrm{E}$ directed, as inferred further north.

These observations suggest that the ScapegoatBannatyne Trend in this area is made up of a series of discrete faults, underlying the complex zones in the thrust sheets. These fault strands appear to be oblique to the regional compression direction. Complexity is noted in the large-scale oroclinal bend to the south of the present study area, which may also be related to the Scapegoat-Bannatyne Trend. Thus, the series of experiments described above and illustrated in Figure 4 was designed, testing the effect of obliquity in the lowersection fault orientation (Model $2 \mathrm{v}$. Model 3, containing one fault, parallel to or oblique to the compression direction) and the effect of multiple lower-section fault strands (Models 3-5, testing the effects of one, two or three fault strands). A final model is designed to demonstrate that the lower-section faults can affect surface deformation patterns even when the upper and lower sections are decoupled by a detachment. This model is not intended to produce structures identical to those in the study area, but to be a proof of concept. These results will be described below.

\section{4.b. Analogue modelling results: map view}

In discussing the analogue model results, we will first consider the models in map view, before comparing representative cross-sections from each model. Figure 8 shows successive map-view images of Model 1 , the model run without any pre-existing faults (Fig. 8a) as a calibration. Thrusts develop close to the moving wall and propagate into the foreland in a piggyback style. The first and second thrusts (Fig. 8b, c) form with a nearly linear trace. The third thrust (Fig. 8d) forms as segments linked by branch lines. Successive thrusts form with some sinuosity and the development of randomly distributed branch lines (Fig. 8e, f, g, h, i). The deflections and segmentation of the thrusts are not systematic, and a clustering of thrust branch lines is not observed. Observation of the model between photographs suggests that thrusts initiate in the centre of the model and propagate to the edges, a situation captured in Figure $6 \mathrm{f}$ and $\mathrm{h}$.

Sequential map-view photographs of Model 2, the model with one pre-existing fault, cut perpendicular to transport direction (Fig. 9a). The first thrusts develop with a slightly sinuous trace (Fig. 9b, c). Thrust 3 

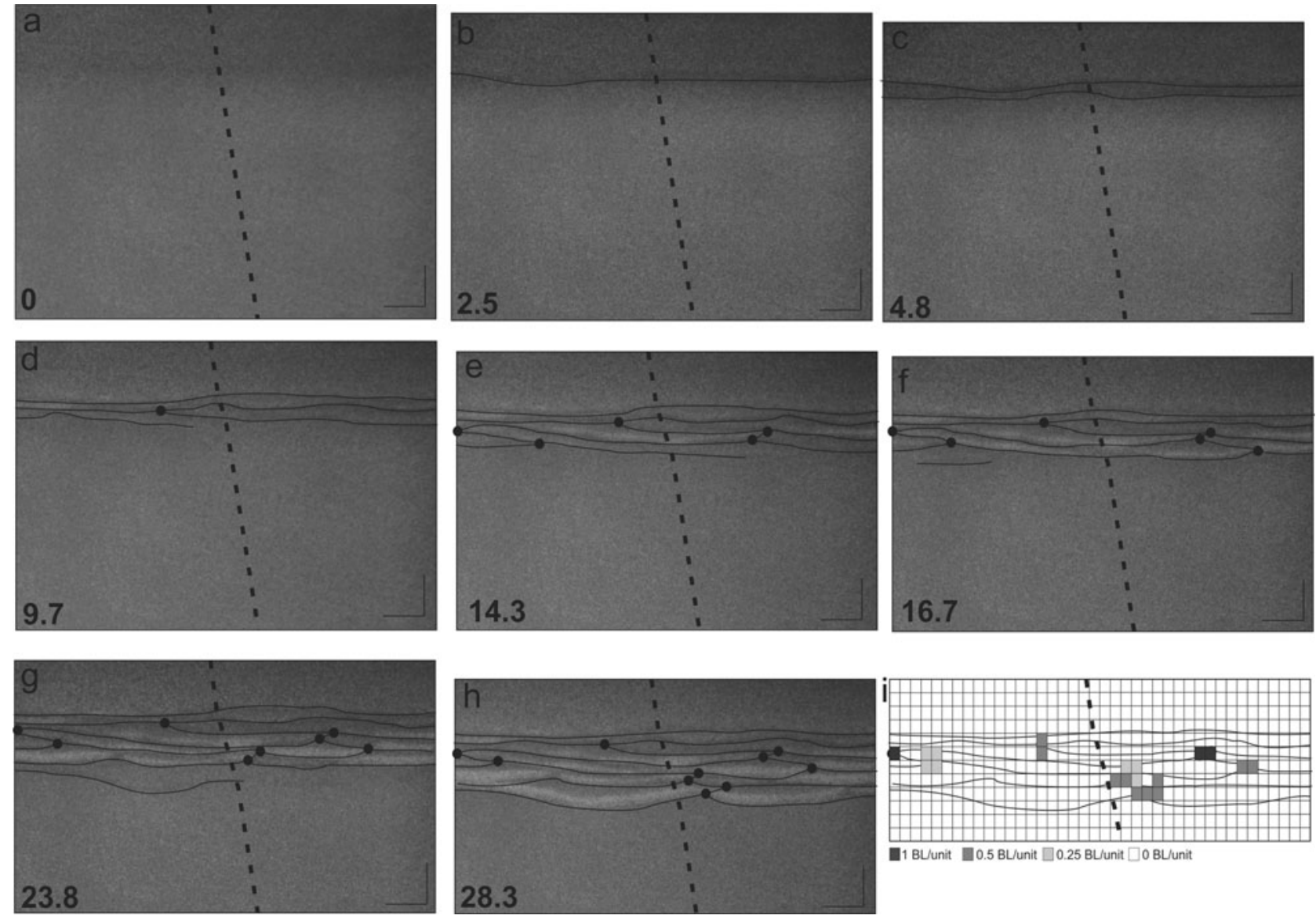

1 1 BLunit $\square 0.5$ BL/unit $\square 0.25$ BL/unit $\square 0$ BL/unit

Figure 10. Same as Figure 8, but for Model 3. The locations of the pre-existing faults are shown.
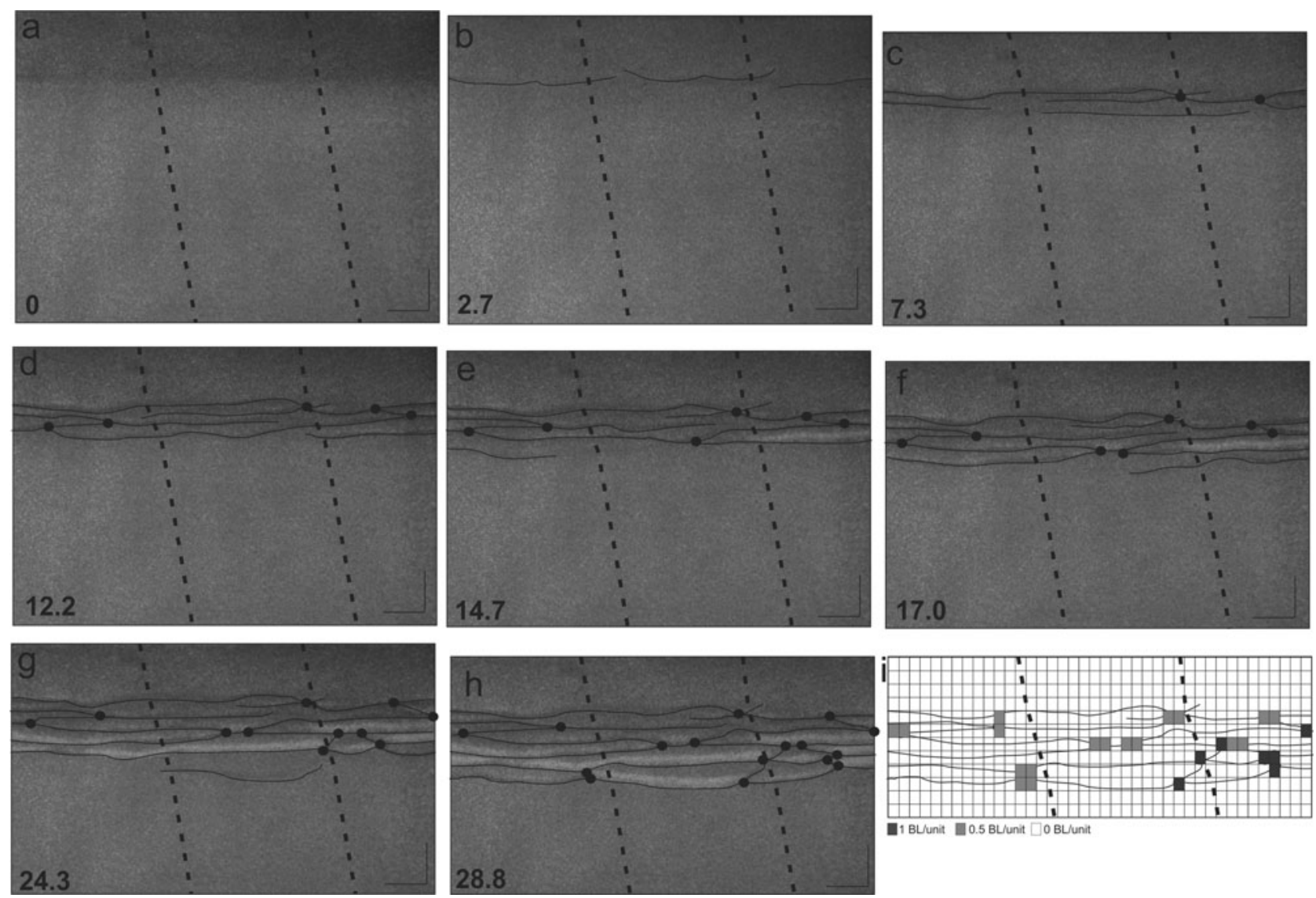

Figure 11. Same as Figure 8, but for Model 4. The locations of the pre-existing faults are shown. 



D1 1 BLunit

Figure 12. Same as Figure 8, but for Model 5. The locations of the pre-existing faults are shown.


Figure 13. Same as Figure 8, but for Model 6. The locations of the pre-existing faults are shown.

develops in two segments, a small segment close to the edge of the box, and a longer, more linear segment (Fig. 9d). Thrust 4 develops in two segments, a shorter one near the edge of the box and a longer segment with some minor deflections in the trace (Fig. 9e). One of the deflections in this trace is close to the location of the pre-existing fault. The next thrust begins to develop in the centre of the model (Fig. 9f) and then propagates across the model with a linear trace (Fig. $7 \mathrm{~g}$ ). Figure $7 \mathrm{~g}$ also shows the next thrust, thrust 6 , initiating in the centre of the model. Again, this thrust propagates across the model with a linear trace (Fig. 9h). Figure 9i shows that the branch lines are not closely clustered around the location of the pre-existing fault. Whilst it is 
Model 1

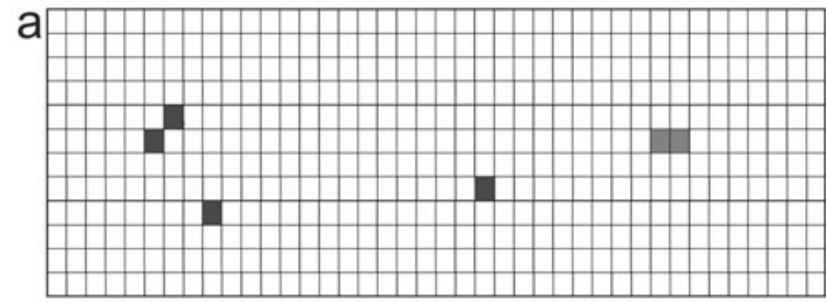

\section{Model 3}

C

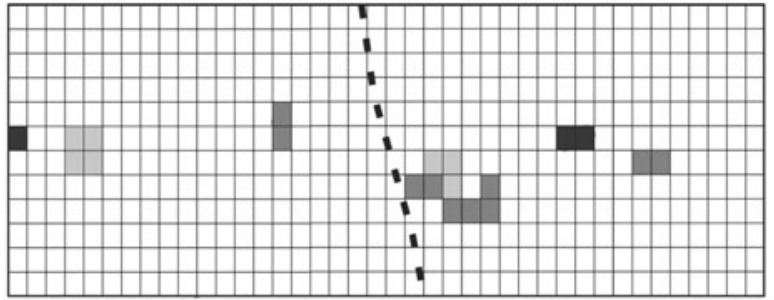

Model 5

e

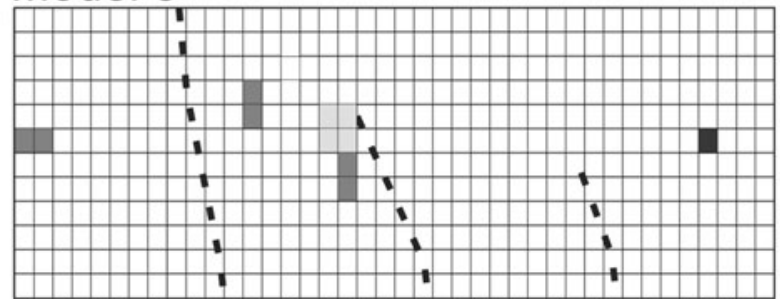

Model 2
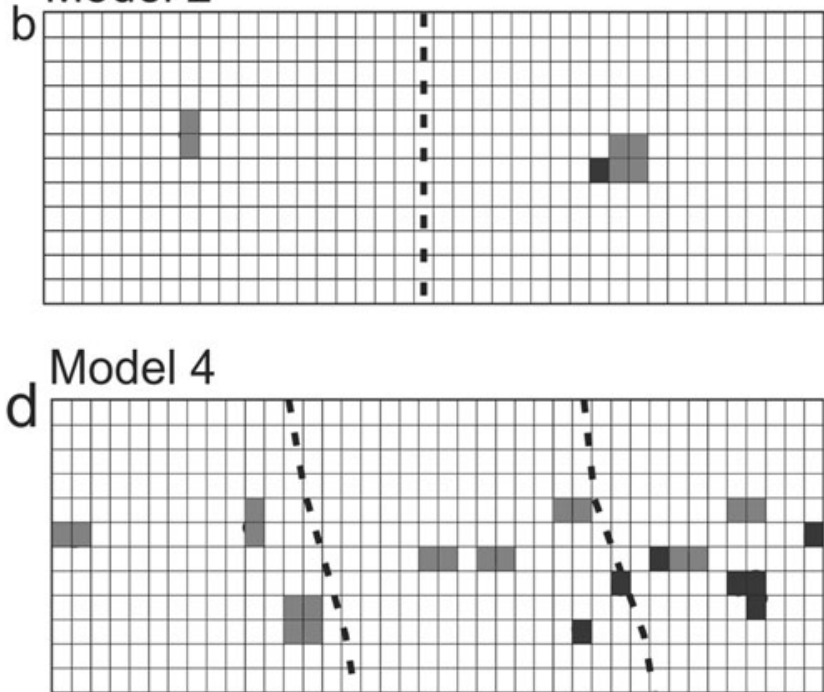

$1 \mathrm{BL} /$ unit $\square 0.5 \mathrm{BL} / \mathrm{unit} \square 0.25 \mathrm{BL} / \mathrm{unit} \square 0 \mathrm{BL} / \mathrm{unit}$

Model 6 not shown, no BL developed

Figure 14. All choropleth maps from Figures 8-12 (Models 1-5) for comparison. Branch lines cluster around the locations of the pre-existing faults.

tempting to ascribe the initiation of thrusts in the centre of the model to the presence of the pre-existing fault, this cannot be defended, as the same occurrence was noted in Model 1.

Figure 10 contains sequential map-view photographs of Model 3. This model contained one preexisting fault, but cut to be slightly oblique to the transport direction (Fig. 10a) following interpretation from the remote images as discussed above. The first thrust develops with a nearly linear trace (Fig. 10b) with a deflection that does not appear related to the pre-existing fault location. The second thrust, however, develops with a deflection around the location of the pre-existing fault (Fig. 10c). The next thrust develops branching off from thrust 2 close to the preexisting fault, and propagating to the edge of the model (Fig. 10d). Figure 10d also shows a thrust developing to one side of the pre-existing fault and propagating between the fault and the model edge. Figure 10e, f shows a series of thrusts developing, initiating from the edge of the model, from deflections in other thrust sheets, or ahead of branch lines in hinterland thrust sheets. Figure $10 \mathrm{~g}$ shows a thrust initiating with a large deflection to one side of the pre-existing fault, and the thrust immediately to the hinterland is segmented, with one segment edge occurring over the pre-existing fault. In the final model configuration (Fig. 10h) this initiating thrust has amplified and there is a pronounced deflection over the pre-existing fault. Compared to the previous two models, this pattern of developing thrusts and branch lines suggests that the presence of the oblique pre-existing fault has disrupted the standard pattern of thrusts initiating in the centre of the model. In addition, the presence of the pre-existing fault appears to promote thrust segmentation, with some branch lines clustering around the location of the pre-existing fault (Fig. 10i).

The sequential development of Model 4 is shown in Figure 11. This model had two faults cut into the lower section, oblique to the direction of transport (Fig. 11a). The first thrust develops as three separate segments, with the segment boundaries above the locations of the pre-existing faults (Fig. 11b). The next thrusts are also segmented (Fig. 11c) and some of the segment boundaries coincide with the locations of the pre-existing faults. The same pattern of segment boundaries above the pre-existing faults, or deflections in the thrust traces above the faults, is observed in Figure 11d. Branch lines tend to fall within a few $\mathrm{cm}$ of the pre-existing fault location. Figure $11 \mathrm{e}$ shows a new thrust initiating between the edge of the model and one of the faults. This thrust merges with a hinterland thrust near a pre-existing fault (Fig. 11f), and a new thrust initiates between the model edge and the other pre-existing fault. In Figure $11 \mathrm{~g}$, the new thrust can be seen initiating between the two pre-existing faults. In the final model configuration (Fig. 11h) this segment has amplified between the pre-existing faults, 

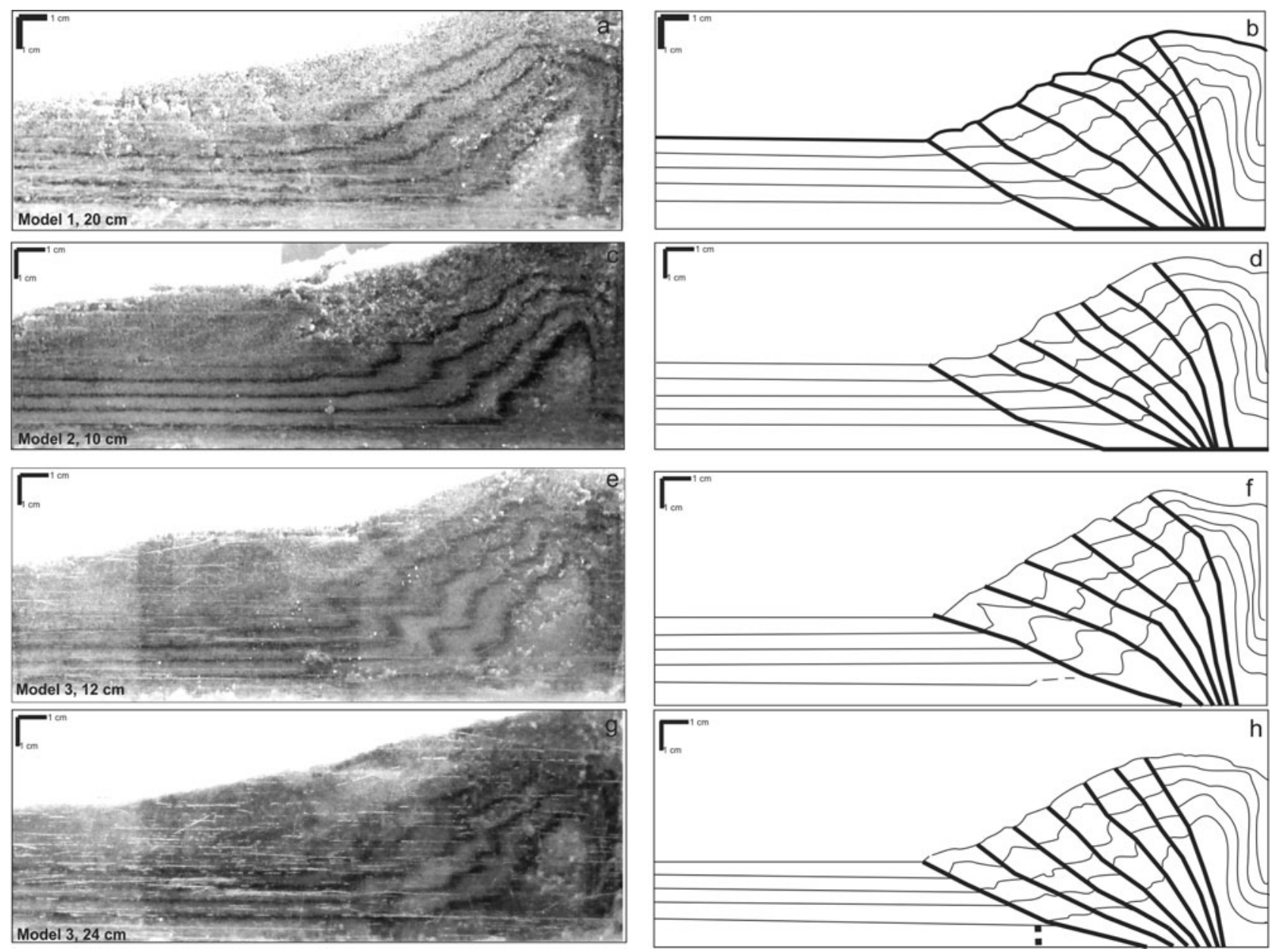

Figure 15. Representative cross-sections from Models 1-3. (a, b) A representative section from Model 1. (c, d) Representative sections from Model 2. $(\mathrm{e}-\mathrm{h})$ Representative sections from Model 3. Thrusts are interpreted in the right-hand line drawings, and the positions of the pre-existing faults are marked where relevant.

and two additional segments have developed. Compared to the previous models, the segmentation of the thrust faults appears to be controlled by the locations of the two pre-existing faults, and the branch lines between thrust faults fall in a zone close to the preexisting fault locations, or cluster near the pre-existing faults (Fig. 11i).

Figure 12 shows the sequential development of Model 5, the model with three right-stepping preexisting faults (Fig. 12a). The first thrust forms with a deflection around one of the pre-existing faults, and divides into two segments near the hinterland of the second pre-existing fault (Fig. 12b). The next thrust also shows a deflection around one of the pre-existing faults, and has not propagated across the whole model (Fig. 12c). The next thrusts to develop form as two segments, with an overlap zone between two of the preexisting faults (Fig. 12d). At this time step, the third pre-existing fault is not yet affecting the developing fold-thrust belt. Figure 12e shows an additional thrust developing between the second pre-existing fault and the edge of the model. This thrust develops across the whole model in the next time step (Fig. 12f) and has a deflection across the middle pre-existing fault. At the same time, a thrust develops which merges with the deflected thrust near the pre-existing fault and propagates to the edge of the model. Figure $12 \mathrm{~g}$ shows the next thrust propagating across the model with a linear trace. In the final model configuration (Fig. 12h) the developing thrust from Figure $12 \mathrm{~g}$ has propagated across the model and has amplified significantly. A final thrust is initiating to the foreland, with a distinct deflection near the middle of the pre-existing faults. This model demonstrates that a deformed foreland region can also affect the developing thrust trace (Fig. 12b). As in the previous model, the segmentation of the thrust faults appears to be controlled by the locations of the pre-existing faults, and the branch lines between thrust faults fall in a zone close to the pre-existing fault locations (Fig. 12i). The middle pre-existing fault in this configuration appears to have the most pronounced effect on the branch line locations, deflections and segmentation of the thrust faults.

Model 6, the proof of concept, has a different stratigraphy from the other models, and as a result the mapview images look very different. Instead of a series of closely spaced thrust faults, large, broad, doubly vergent structures develop in the model (Fig. 13). Two faults are cut into the lower section of the model (Fig. 13a), and the cover sequence is separated from the 

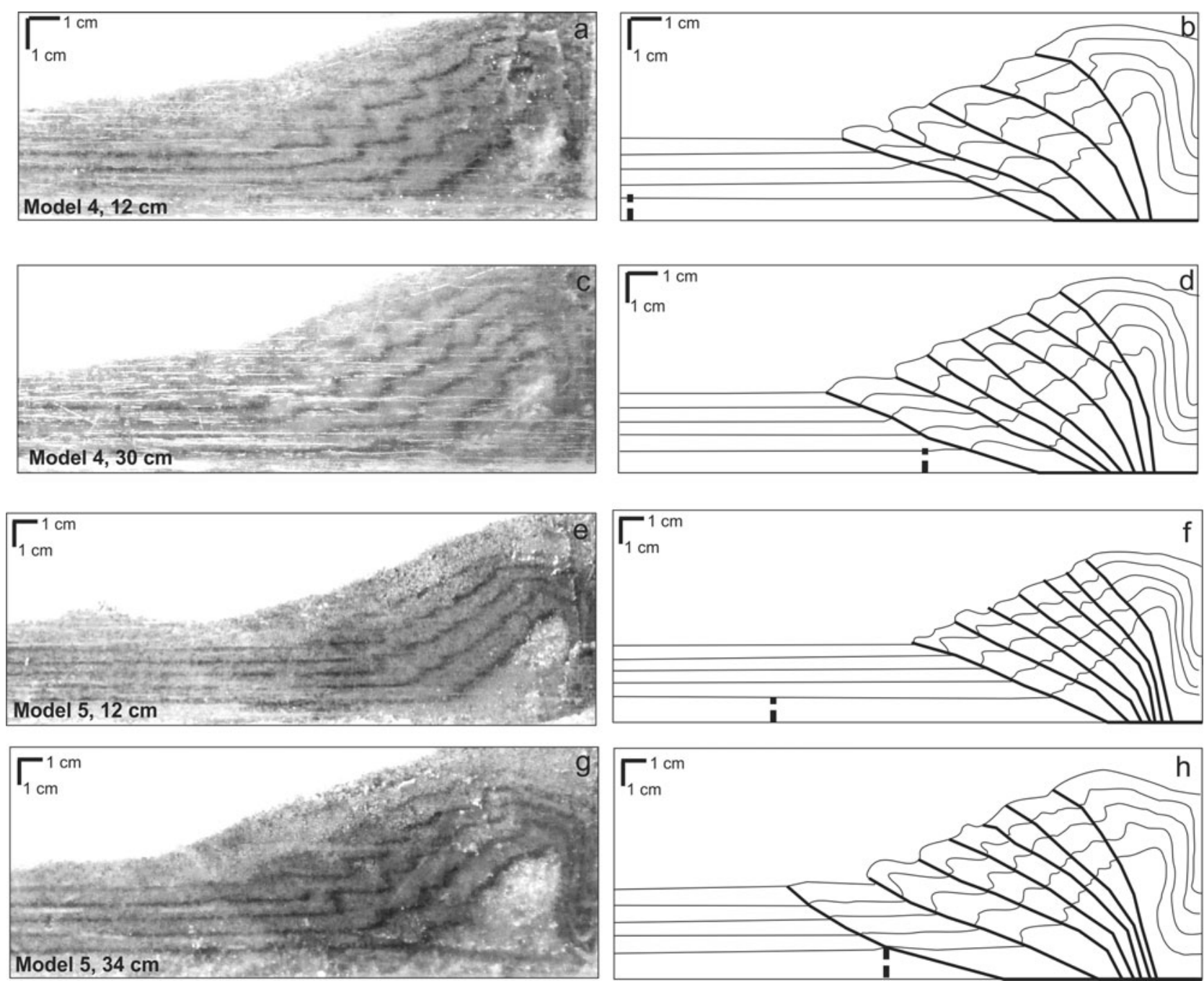

Figure 16. Representative cross-sections from Models 4-5. (a-d) Representative sections from Model 4. (e-h) Representative sections from Model 5. Thrusts are interpreted in the right-hand line drawings, and the positions of the pre-existing faults are marked where relevant.

lower section by a ductile layer that covers the entire width of the model, and the first $30 \mathrm{~cm}$ used in analysis. The first thrust develops across the model with subtle deflections that may be related to the positions of the two faults (Fig. 13b). Displacement on this fault continues to accumulate, creating a large folded structure (Fig. 13c), and the deflections on the thrust trace are masked. Once the second thrust starts to develop, slight deflection can be seen on the trace, again possibly related to the locations of the pre-existing faults (Fig. 13d). The third fore-thrust in the model develops with a clear deflection around one of the imposed preexisting faults although there is limited influence from the other fault (Fig. 13e). In the final configuration, a backthrust can be identified, related to this third foldthrust feature (Fig. 13f). The backthrust trace geometry mimics that of the fore-thrust. This model demonstrates that although the presence of the ductile layer mutes the influence of the pre-existing faults, and changes the deformation style of the model, the surface thrust geometries can still be influenced by lower-section heterogeneity.
Figure 14 shows all choropleth maps from Models $1-5$, showing clustering of branch lines around the preexisting faults, and an increase in branch lines in models with faults compared to Model 1 . The pre-existing faults which are slightly oblique to the compression direction affect the geometry of the thrust traces developed in the cover sequence, but there is no discernible effect from a pre-existing fault parallel to the compression direction. Where there are multiple faults in the preexisting, the interaction between those faults enhances the effect of the faults and promotes segmentation of the surface thrusts and the development of clusters of branch lines around the pre-existing fault traces.

\section{4.c. Analogue modelling results: cross-section view}

In cross-section, thrust faults and associated folding in the layers can be identified in representative crosssections from each model. In Model 1, the thrust faults become steeper to the hinterland, as expected for piggyback-style thrusting. Offsets on individual thrusts are relatively small, and deformation is also 


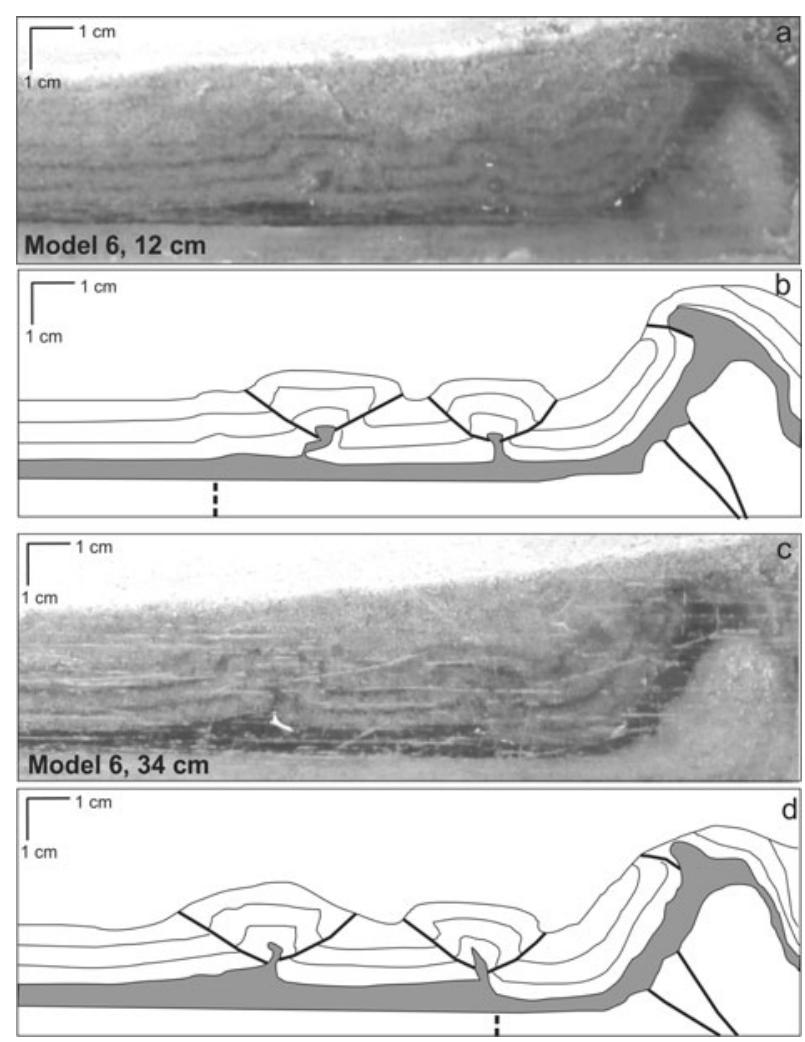

Figure 17. Representative cross-sections from Model 6. Thrusts and the deformation of the ductile layer are interpreted in the line drawings in (b) and (d), and the positions of the pre-existing faults are marked.

accommodated by folding (Fig. 15 a, b). In Model 2, representative cross-sections (Fig. 15c, d) cannot be geometrically distinguished from the cross-section from Model 1. A cross-section from the zone in Model 3 that is unaffected by the pre-existing faults contains fewer thrusts than in Models 1 and 2, but is geometrically similar to the previous representative crosssections (Fig. 15 e, f). A subtle change in the angle of the youngest thrust may be observed in Model 3, where the thrust overlies the pre-existing fault (Fig. $15 \mathrm{~g}, \mathrm{~h}$ ), but the marker representing the top of the lower section does not appear to be deformed. In other respects, the geometry of the fold-thrust belt is similar to that noted in other representative sections in Figure 15. In Model 4 , a representative section away from the pre-existing fault (Fig. 16a, b) shows a geometry similar to representative sections from Figure 15. There may be a slight change in the angle of the thrust overlying the preexisting fault in Model 4 (Fig. 16c, d) but again the top lower-section marker does not appear to be deformed. Similar results are noted in Model 5, that the region of the model away from any pre-existing faults resembles a typical fold-thrust belt as in the other models (Fig. 16e, f). A slight change in the thrust angle and possible subtle deformation of the top lower-section marker unit may be observed where the frontal thrust crosses the pre-existing fault (Fig. 16g, h). Figure 17 shows representative sections from Model 6. This cross-section contains the characteristic doubly vergent pop-up type

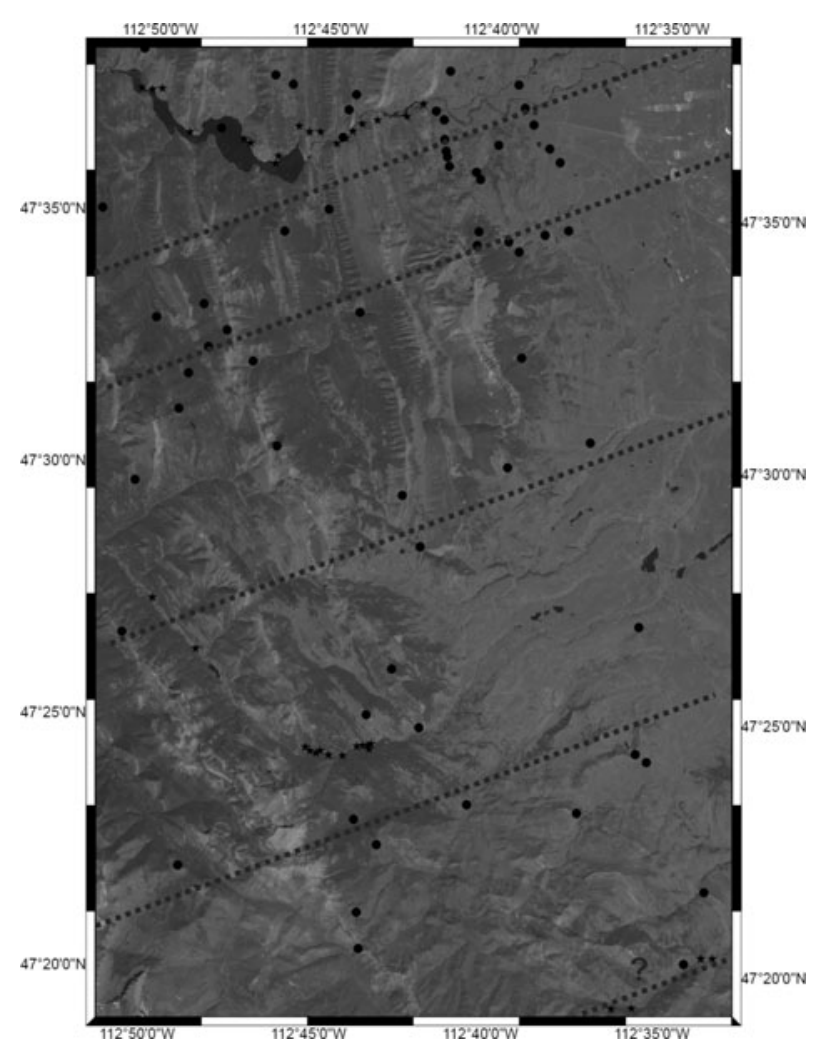

Figure 18. Structural map of the study area overlain on the satellite image from Figure 3. The positions of proposed basement fault strands are marked with heavy dashed lines.

structures expected when a brittle unit overlies a ductile detachment. Some interaction of the pre-existing faults can be identified in both representative sections. In the first section (Fig. 17a, b) the ductile layer thickens slightly above the pre-existing fault, and a small fold begins to develop in the cover. A similar thickening in the ductile layer is observed above the pre-existing fault in the second cross-section (Fig. 17c, d). To the foreland of the pre-existing fault, the ductile layer has thickened, and to the hinterland the ductile layer has thinned.

In summary, the pre-existing faults do not appear to markedly influence the geometry of the thrust sheets in cross-section. In an entirely brittle system, there may be slight variation in the trajectory of the thrust sheet directly overlying the pre-existing fault, but the effect is subtle. In the system decoupled by a ductile layer, there are subtle thickness changes in the ductile layer directly overlying the pre-existing faults. In neither scenario do the pre-existing faults explicitly appear to reactivate as dip-slip faults and propagate into the cover.

\section{Discussion}

Our results have demonstrated that complexity in surface thrust sheets can be related to heterogeneity within the lower sedimentary section. This complexity is best observed in the map-view thrust traces, as the models do not show the lower-cover faults propagating into the upper cover. The lower-cover faults are more 




$100 \mathrm{~km}$

Figure 19. Major density boundaries (solid lines) within the middle to upper crust, marking structural trends in the study area. Base map is from Mankinen et al. (2004). The dotted line marks the approximate deformation front of the Sawtooth Range, and the grey area marks the extent of the Rocky Mountains in this region. The black box marks the present study area, that shown in Figures 3, 5 and 18. The arrowed density boundaries are interpreted to be faults within the GFTZ that continue into the study area and are consistent with predicted faults in Figure 18.

likely to be reactivated as strike-slip features, given the low obliquity between compression direction and fault orientation. These results are consistent with findings from Richard (1991) and Richard, Naylor \& Koopman (2008), that obliquity of the pre-existing fault with respect to the compression is a controlling factor on reactivation, and that decoupling basement and cover by a ductile horizon mutes the influence of a basement fault but does not completely mask it.

\section{5.a. Predicted basement faults in the Scapegoat-Bannatyne Trend in the Sawtooth Range}

Based on these results, we predict four to five discrete fault strands in the basement of the study area (Fig. 18). Each strand is oriented NE-SW, following the orientation of the Scapegoat-Bannatyne Trend (Fig. 1). Each strand passes through a region of non-linear thrust faulting, as described previously. One fault strand passes south of the Gibson Dam area, with additional faults forming to the SW. A further strand is proposed further south, and there may also be a basement fault passing through the Cataract Falls area. We postulate that the interaction between the basement fault and the oblique transport direction promotes the complex deformation observed in the thrust sheet in this area.

These predictions are consistent with other work in the region. Reinecke (1989) notes several discrete faults in the overlying Precambrian thrust sheet (grey shaded in Fig. 1) in the same area and with the same orientation as our proposed faults. Alpha (1955) shows a map in which the Scapegoat-Bannatyne Trend is predicted to divide into two strands close to our southernmost two fault strands in Figure 18. In addition, processed aeromagnetic and gravity anomaly data from Mankinen et al. (2004) indicate that there are at least two NE-SW-oriented lineaments in the study area (arrowed in Fig. 19).

\section{5.b. Limitations of the models in this study}

These models are most applicable to thrust belts that are considered thin-skinned, without significant basement involvement. We have assumed that the lower cover 
section is heterogeneous, whereas the upper cover is not. Our results could also be applied to the hinterland of fold-thrust belts, where basement rocks are involved in the thrust sheets along with cover rocks. One example of this situation is the Kishenen Basin in southern Alberta, where Proterozoic units are involved in the major thrust sheets (Fuentes, DeCelles \& Constenius, 2012). Another situation where basement units are involved in thrusting is the Magura zone of the northern Carpathians, Slovakia, where slivers of the basal Marmarosh Ridge are incorporated into thrust sheets (Gagala et al. 2012). A third example of hinterland basement involvement in thrust sheets comes from the eastern Dolomites, Italy, where significant thrusts in the basement section are interpreted to underlie the Croda Russa to Mount Grappa region (Schonborn, 1999). The numerical models of Nilfouroushan et al. (2013) indicate that basement involvement in hinterland thrust sheets is most likely where the brittle-ductile transition zone is deep within the basement units.

No analogue model in this study exactly reproduced the cross-sectional geometry of the Sawtooth Range, a foreland-verging series of Palaeozoic thrust sheets, as mapped by Holl \& Anastasio (1992) or Fuentes et al. (2011). The brittle models (Models 1-5) show greater involvement of the lower layer in the deformation than is seen in nature. In nature, the Palaeozoic thrust sheets detach within the Devonian sequence in the Gibson Reservoir area (Holl \& Anastasio, 1992) and in the upper Cambrian units in the Cataract Falls area (Raines \& Johnson, 1995). However, in our Model 6, the ductile material is a more accurate representation of the behaviour of a salt system, rather than the shale and limestone nature of the detachment in the region (Deiss, 1943). This means that the modelled situation decouples the lower units and the upper cover more efficiently than the natural situation is expected to. Thus, the effect of the basement faults is expected to be less pronounced in nature than in Models 4 and 5, where the multiple basement fault strands generate significant complexity in the overlying thrust sheets. However, the effect of the basement faults is not expected to be as muted as in Model 6. We also did not attempt to model the larger-scale curvature of the Sawtooth Range in this area, as this is outside the limits of the apparatus available to us. Nonetheless, despite these caveats, we consider that our models are informative and valuable in demonstrating the likely evolution of a fold-thrust belt deforming above a basement with multiple existing fault strands.

\section{Conclusions}

This study has considered the effects of basement faults on overlying thrust systems, with application to the Sawtooth Range, Montana. Our results have demonstrated that complexity in surface thrust sheets can be related to heterogeneity within the basement or lower cover, even when there is a detachment between the faulted unit and the remaining cover. This complexity is best observed in the map-view thrust traces, as the models do not show the lower-cover faults propagating into the cover. The basement faults are more likely to be reactivated as strike-slip features, given the low obliquity between compression direction and fault orientation. In map view, the lower-cover faults which are slightly oblique to the compression direction affect the geometry of the thrust traces developed in the cover sequence, but there is no discernible effect from a lower-cover fault parallel to the compression direction. Where there are multiple faults in the lower cover, the interaction between those faults enhances the effect of the faults and promotes segmentation of the surface thrusts. En échelon lower-cover faults promote the most segmentation of the surface thrusts. These results were then applied to the study area in the Sawtooth Range, predicting five discrete fault strands associated with what is generally mapped as the Scapegoat-Bannatyne Trend. More generally, these results can be used to govern evaluation of thrust belts deforming over faulted basement, and to predict the locations of specific fault strands in a region where this information is unknown.

Acknowledgements. We thank two anonymous reviewers for comments which improved the manuscript, and Jonas Ruh for editorial comment. J.M.P. thanks Jake Bruihler for assistance in the field. We would also like to thank undergraduate researchers Amanda Jones and Bailey Lathrop, as well as graduate research assistant Matthew Peppers for invaluable assistance in running and slicing the various models in this suite.

\section{References}

Allen, M. B. \& VincenT, S. J. 1997. Fault reactivation in the Junggar region, northwest China: the role of basement structures during Mesozoic-Cenozoic compression. Journal of the Geological Society 154, 151-5.

ALPHA, A. G. 1955. Tectonic history of north central Montana. In Billings Geological Society Handbook, Sixth Annual Field Conference, pp. 129-42. Billings, MT: Billings Geological Society.

AudET, P. \& BurgmanN, R. 2011. Dominant role of tectonic inheritance in supercontinent cycles. Nature Geoscience 4, 184-7. doi: 10.1038/ngeo1080.

BAHROUDI, A. \& KOYI, H. A. 2003. Effect of spatial distribution of Hormuz salt on deformation style in the Zagros fold and thrust belt: an analogue modelling approach. Journal of the Geological Society 160, 719-33.

BAHROUDI, A. \& TALBOT, C. J. 2003. The configuration of the basement beneath the Zagros Basin. Journal of Petroleum Geology 26(3), 257-82.

Boerner, D. E., Craven, J. A., Kurtz, R. D., Ross, G. M. \& JonES, F. W. 1998. The Great Falls Tectonic Zone: suture or intracontinental shear zone? Canadian Journal of Earth Sciences 35(2), 175-83.

BOYER, S. E. 1992. Geometric evidence for synchronous thrusting in the southern Alberta and northwest Montana thrust belts. In Thrust Tectonics (ed. K. R. McClay), pp. 377-90. Berlin: Springer.

BOYER, S. E. 1995. Sedimentary basin taper as a factor controlling the geometry and advance of thrust belts. American Journal of Science 295, 1220-54. 
BURBERRY, C. M. 2015a. The effect of basement fault reactivation on the Triassic-Recent geology of Kurdistan, N Iraq. Journal of Petroleum Geology 38(1), 37-58.

BURBERRY, C. M. 2015b. Spatial and temporal variation in penetrative strain during compression: insights from analog models. Lithosphere 7, 611-24. doi: 10.1130/L454.1.

Butler, R. W. H., Tavarnelli, E. \& Grasso, M. 2006. Structural inheritance in mountain belts: an AlpineApennine perspective. Journal of Structural Geology 28, 1893-908.

CHILDERS, N. 1963. Structure and stratigraphy of the SW Marias Pass area, Flathead County, Montana. Geological Society of America Bulletin 74, 141-64.

Daly, R. A., Manger, G. E. \& ClarK, JR, S. P. 1966. Density of rocks. In Handbook of Physical Constants (ed. S. P. Clark, Jr), pp. 19-26. Geological Society of America Memoir 97. doi: 10.1130./MEM97-p19.

DeCELles, P. G. 2004. Late Jurassic to Eocene evolution of the Cordilleran thrust belt and foreland basin system, western USA. American Journal of Science 304(2), 105-68.

DEISS, C. 1943. Structure of central part of Sawtooth Range, Montana. Bulletin of the Geological Society of America 54, 1123-68.

DICKINSON, W. R. 2004. Evolution of the North American Cordillera. Annual Review of Earth and Planetary Sciences 32, 13-45.

Dickinson, W. R. \& GeHRELs, G. E. 2003. U-Pb ages of detrital zircons from Permian and Jurassic eolian sandstones of the Colorado Plateau, USA: paleogeographic implications. Sedimentary Geology 163, 29-66.

FINN, C. A. \& SIMS, P. K. 2005. Signs from the Precambrian: the geologic framework of Rocky Mountain Region derived from aeromagnetic data. In The Rocky Mountain Region: An Evolving Lithosphere (eds K. E. Karlstrom \& G. R. Keller), pp. 39-54. Geophysical Monograph 154.

Fuentes, F., DeCelles, P. G. \& Constenius, K. N. 2012. Regional structure and kinematic history of the Cordilleran fold-thrust belt in northwestern Montana, USA Geosphere 8, 1104-28. doi: 10.1130/GES00773.1.

Fuentes, F., DeCelles, P. G., Constenius, K. N. \& GEHRELS, G. E. 2011. Evolution of the Cordilleran foreland basin system in northwestern Montana, USA. Geological Society of America Bulletin 123, 507-33.

Gagala, L., Verges, J., SAURA, E., MalatA, T., RINGENBACH, J.-C., WERNER, P. \& KRZYWIEC, P. 2012. Architecture and orogenic evolution of the northeastern Outer Carpathians from cross-section balancing and forward modeling. Tectonophysics 532-5, 223-41.

GARDNER, S. P. \& ACHUFF, J. M. 1989. Structural interpretation of the southern half of the Sawtooth Salient of the Montana Disturbed Belt. In Montana Geological Society: 1989 Field Conference Guidebook: Montana Centennial Edition. Geologic Resources of Montana, vol. 1 (eds D. F. French \& R. F. Grabb), pp. 231-48. Billings, MT: Montana Geological Society.

GUTOWSKI, J. \& KOYI, H. A. 2007. Influence of oblique basement strike-slip faults on the Mesozoic evolution of the south-eastern segment of the Mid-Polish Trough. Basin Research 19(1), 67-86.

Hardebol, N. J., Callot, J. P., Faure, J. L., Bertotti, G. \& Roure, F. 2007. Kinematics of the SE Canadian fold-thrust belt: implications for the thermal and organic maturation history. In Thrust Belts and Foreland Basins (eds O. Lacombe, J. Lave, F. Roure \& J. Verges), pp. 179-202. Berlin: Springer.
Hessami, K., Koyi, H. A. \& TAlbot, C. J. 2001. The significance of strike-slip faulting in the basement of the Zagros fold and thrust belt. Journal of Petroleum Geology 24, $5-28$.

Holdsworth, R. E., Butler, C. A. \& Roberts, A. M. 1996. The recognition of reactivation during continental deformation. Journal of the Geological Society 154, 738.

Holl, J. E. \& AnASTASiO, D. J. 1992. Deformation of a Foreland Carbonate Thrust System, Sawtooth Range, Montana. Geological Society of America Bulletin 104(8), 944-53.

HoLM, D. \& SCHNEIDER, D. $2002 .{ }^{40} \mathrm{Ar}-{ }^{39} \mathrm{Ar}$ for ca. $1800 \mathrm{Ma}$ tectonothermal activity along the Great Falls Tectonic Zone. Canadian Journal of Earth Sciences 39, 171928.

HuerTA, A. D. \& HARRY, D. L. 2012. Wilson cycles, tectonic inheritance, and rifting of the North American Gulf of Mexico continental margin. Geosphere 8, 374-85.

KOYI, H. \& PETERSEN, K. 1993. Influence of basement faults on the development of salt structures in the Danish Basin. Marine and Petroleum Geology 10(2), 82-94.

KULIK, D. 1982. Preliminary gravity study of Glacier National Park, Montana. In Geological Studies of the Cordilleran Thrust Belt: Rocky Mountain Association of Geologists Symposium (ed. R. B. Powers), vol. 1, pp. 459-65.Denver, CO: Rocky Mountain Association of Geologists.

Lacombe, O., Mouthereau, F., Angelier, J., Chu, H.T. \& LEE, J.-C. 2003. Frontal belt curvature and oblique ramp development at an obliquely collided irregular margin: geometry and kinematics of the NW Taiwan fold-thrust belt. Tectonics 22(3), 1025. doi: 10.1029/2002TC001436.

LETOUZEY, J. 1990. Fault reactivation, inversion and foldthrust belts. In Petroleum and Tectonics in Mobile Belts (ed. J. Letouzey), pp. 101-28. Paris: Editions Technip.

LickORISH, W. H., FORD, M., Burgisser, J. \& COBBOLD, P. R. 2002. Arcuate thrust systems in sandbox experiments: a comparison to the external arcs of the Western Alps. Geological Society of America Bulletin 114(9), 1089107.

LORENZ, J. C. 1982. Lithospheric flexure and the history of the Sweetgrass Arch, NW Montana. In Geological Studies of the Cordilleran Thrust Belt: Rocky Mountain Association of Geologists Symposium (ed. R. B. Powers), vol. 1, pp. 77-89. Denver, CO: Rocky Mountain Association of Geologists.

MACEDO, J. \& MARSHAK, S. 1999. Controls on the geometry of fold-thrust belt salients. GSA Bulletin 111(12), 180822.

Maillot, B. \& KoYI, H. 2006. Thrust dip and thrust refraction in fault-bend folds: analogue models and theoretical predictions. Journal of Structural Geology 28(1), 36-49.

Mankinen, E. A., Hildenbrand, T. G., ZienteK, M. L., Box, S. E., Bookstrom, A. A., CArlson, M. A. \& LARSEN, J. C. 2004. Guide to geophysical data for the Northern Rocky Mountains and adjacent areas, Idaho, Montana, Washington, Oregon and Wyoming. USGS Open-File Report 2004-1413.

MARShaK, S., WiLKerson, M. S. \& Hsui, A. T. 1992. Generation of curved fold-and-thrust belts: insight from simple physical and analytical models. In Thrust Tectonics (ed. K. R. McClay), pp. 83-92. London: Chapman and Hall.

McMechan, M. E. 2012. Deep transverse basement structural control of mineral systems in the southeastern $\mathrm{Ca}$ - 
nadian Cordillera. Canadian Journal of Earth Sciences 49(5), 693-708, doi: 10.1139/e2012-013.

Molliex, S., Bellier, O., Terrier, M., Lamarche, J., MARTElet, G. \& EspurTA, N. 2010. Tectonic and sedimentary inheritance on the structural framework of Provence (SE France): importance of the SalonCavaillon fault. Tectonophysics 501, 1-16.

Morley, C. K. 1999. How successful are analog models in addressing the influence of pre-existing fabrics on rift structure? Journal of Structural Geology 21, $1267-74$.

MudGe, M. R. 1982a. Geologic and structure map of the Choteau $1 \times 2$ degree quadrangle, Western Montana. USGS Miscellaneous Investigations Series I-1300.

MudGe, M. R. 1982b. A resume of the structural geology of the northern disturbed belt, NW Montana. In Geological Studies of the Cordilleran Thrust Belt: Rocky Mountain Association of Geologists Symposium (ed. R. B. Powers), vol. 1, pp. 91-122. Denver, CO: Rocky Mountain Association of Geologists.

MudGE, M. R. \& EARHART, R. L. 1977. Northeast-trending lineaments in the northern disturbed belt, northwestern Montana. Abstracts with Programs - Geological Society of America 9(6), 750.

MudGe, M. R. \& EARHART, R. L. 1979. Structure and structure contour maps of the Choteau 1 degree by 2 degree Quadrangle, Lewis and Clark, Teton, Powell, Missoula, Lake, Flathead and Cascade Counties, Montana. USGS Open File Report 79-863.

Mudge, M. R. \& EARHART, R. L. 1980. The Lewis Thrust Fault and related structures in the disturbed belt, NW Montana. Geological Survey Professional Paper 1174.

Mueller, P. A., Heatherington, A. L., Kelly, D. M., Wooden, J. L. \& MogK, D. W. 2002. Paleoproterozoic crust within the Great Falls tectonic zone: implications for the assembly of southern Laurentia. Geology 30(2), 127-30.

NAPIER, N. J. 1982. Knowlton Gas Field, Teton County, Montana. In Geological Studies of the Cordilleran Thrust Belt: Rocky Mountain Association of Geologists Symposium (ed. R. B. Powers), vol. 2, pp. 575-9. Denver, CO: Rocky Mountain Association of Geologists.

NiCHOLS, K. M. 1983. Facies in upper part of Madison Group, Sawtooth Range, northwestern Montana. American Association of Petroleum Geologists Bulletin 67, 1350.

Nilfouroushan, F., Pysklywec, R., Cruden, A. \& Koyi, H. 2013. Thermal-mechanical modeling of salt-based mountain belts with pre-existing basement faults: application to the Zagros fold and thrust belt, southwest Iran. Tectonics 32, 1212-26.

O’NeILL, J. M. \& LOPEZ, D. A. 1985. Character and regional significance of Great Falls Tectonic Zone, east-central Idaho and west-central Montana. American Association of Petroleum Geologists Bulletin 69(3), 437-47.

PAull, R. K. \& PAUll, R. A. 1991. Stratigraphic and structural relations of Lower Triassic rocks within the frontal fold-and-thrust zone of southwestern Montana. American Association of Petroleum Geologists 75, 1135.

PinheIRO, R. V. L. \& HOLDSWORTH, R. E. 1997. Reactivation of Archean strike-slip fault systems, Amazon region, Brazil. Journal of the Geological Society 154, 99-103.

RAINES, G. L. \& JOHNSON, B. R. 1995. Digital representation of the Montana state geologic map in ARC/INFO export format. USGS Open-File Report 95-0691.

REINECKE, K. M. 1989. Effect of Scapegoat-Bannatyne Trend on structural development of Montana Disturbed Belt. In Montana Geological Society: 1989 Field Con- ference Guidebook: Montana Centennial Edition. Geologic Resources of Montana, vol. 1 (eds D. F. French \& R. F. Grabb), pp. 249-60. Billings, MT: Montana Geological Society.

RICHARD, P. 1991. Experiments on faulting in a two-layer cover sequence overlying a reactivated basement fault with oblique slip. Journal of Structural Geology 13, 459-69.

RiCHARD, P. \& KRANTZ, R. W. 1991. Experiments on fault reactivation in strike-slip mode. Tectonophysics 188, 117 31.

Richard, P., MocqueT, B. \& CoBbold, P. R. 1991. Experiments on simultaneous faulting and folding above a basement wrench fault. Tectonophysics 188, 133-41.

Richard, P. D., NAYlor, M. A. \& Koopman, A. 2008. Experimental models of strike-slip tectonics. Petroleum Geoscience 1, 71-80.

SAID, A., BABY, P., ChARDON, D. \& OUALI, J. 2011. Structure, paleogeographic inheritance, and deformation history of the southern Atlas foreland fold and thrust belt of Tunisia. Tectonics 30. doi: 10.1029/2011TC002862.

SCHELLART, W. 2000. Shear test results for cohesion and friction coefficients for different granular materials: scaling implications for their usage in analogue modelling. Tectonophysics 324, 1-16.

SCHONBORN, G. 1999. Balancing cross-sections with kinematic constraints: the Dolomites (northern Italy). Tectonics 18, 517-45.

Schreurs, G., Buiter, S. J. H., Boutelier, D., Corti, G., Costa, E., Cruden, A. R., Daniel, J., Hoth, S., KoYI, H. A., KUKOWSKI, N., LOHRMANN, J., RaVAGLIA, A., Schlische, R. W., Withuack, M. O., Yamada, Y., Cavozzi, C., Del Ventisette, C., Brady, J. A. E., Hoffman-Rothe, A., Mengus, J., Montanari, D. $\&$ Nilforoushan, F. 2006. Analogue benchmarks of shortening and extension experiments. In Analogue and Numerical Modelling of Crustal-Scale Processes (eds S. J. H. Buiter \& G. Schreurs), pp. 1-27. Geological Society of London Special Publication no. 253.

SeArs, J. W. \& PRICE, R. A. 2002. The hypothetical Mesoproterozoic supercontinent Columbia: implications of the Siberian - West Laurentian connection. Gondwana Research 5(1), 35-9.

SePeHr, M. \& Cosgrove, J. W. 2005. Role of the Kazerun Fault Zone in the formation and deformation of the Zagros Fold-Thrust Belt, Iran. Tectonics 24. doi: 10.1029/2004TC001725.

Sims, P. K., O’NeILl, J. M., BANKeY, V. \& ANDERSON, E. 2004. Precambrian Basement Geologic Map of Montana - An Interpretation of Aeromagnetic Anomalies. United States Geological Survey Scientific Investigations Map 2829.

SINGDAHLSEN, D. S. 1984. Structural geology of Swift Reservoir culmination, Sawtooth Range, Montana. Bulletin of theAmerican Association of Petroleum Geologists 68(7), 949.

ThOMAS, W. A. 1977. Evolution of Appalachian-Ouachita salients and recesses from re-entrants and promontories in continental-margin. American Journal of Science 277(10), 1233-78.

Thomas, W. A. 2004. Genetic relationship of riftstage crustal structure, terrane accretion, and foreland tectonics along the southern AppalachianOuachita orogen. Journal of Geodynamics 37(3-5), 549-63.

Viola, G., Odonne, F. \& MANCKTElow, N. 2004. Analogue modelling of reverse fault reactivation in strike-slip and transpressive regimes: application to the Giudicarie fault 
system, Italian eastern Alps. Journal of Structural Geo$\log y$ 26, 401-18.

WeiJermars, R. 1992. Progressive deformation in anisotropic rocks. Journal of Structural Geology 14(6), 72342.

Weil, A. \& Sussman, A. J. 2004. Classifying curved orogens based on timing relationships between structural development and vertical-axis rotations. In Orogenic Curvature, Integrating Paleomagnetic and Structural Analyses (eds A. J. Sussman \& A. B. Weil).
Geological Society of America Special Paper 383, pp. 1-15.

Windley, B. F. 1986. The Evolving Continents, 2nd edn. Chichester: John Wiley \& Sons.

Yoos, T. R., Potter, C. J., Thigpen, J. L. \& Brown, L. D. 1991. The Cordilleran foreland fold thrust belt in northwestern Montana and northern Idaho from COCORP and industry seismic reflection data. American Association of Petroleum Geologists Bulletin 75(6), 1089-106. 